\title{
Environmental forcing of the Campeche cold-water coral province, southern Gulf of Mexico
}

\author{
D. Hebbeln ${ }^{1}$, C. Wienberg ${ }^{1}$, P. Wintersteller ${ }^{1}$, A. Freiwald ${ }^{2}$, M. Becker ${ }^{1}$, L. Beuck ${ }^{2}$, C. Dullo ${ }^{3}$, G. P. Eberli ${ }^{4}$, \\ S. Glogowski ${ }^{3}$, L. Matos ${ }^{1,5,6}$, N. Forster ${ }^{2}$, H. Reyes-Bonilla ${ }^{7}$, M. Taviani ${ }^{8,9}$, and the MSM 20-4 shipboard scientific \\ party \\ ${ }^{1}$ Center for Marine Environmental Sciences (MARUM), University of Bremen, Bremen, Germany \\ ${ }^{2}$ Senckenberg am Meer, Marine Research Department, Wilhelmshaven, Germany \\ ${ }^{3}$ Helmholtz Centre for Ocean Research Kiel (GEOMAR), Kiel, Germany \\ ${ }^{4}$ Rosenstiel School for Marine and Atmospheric Science (RSMAS), University of Miami, Miami, USA \\ ${ }^{5}$ Instituto Portugues do Mar e da Atmosfera (IPMA), Lisbon, Portugal \\ ${ }^{6}$ Centro de Estudos do Ambiente e do Mar (CESAM), Aveiro, Portugal \\ ${ }^{7}$ Universidad Autónoma de Baja California Sur, La Paz, Mexico \\ ${ }^{8}$ Institute of Marine Sciences, National Research Council, Bologna, Italy \\ ${ }^{9}$ Biology Department, Woods Hole Oceanographic Institution, Woods Hole, USA
}

Correspondence to: D. Hebbeln (dhebbeln@marum.de)

Received: 30 October 2013 - Published in Biogeosciences Discuss.: 28 November 2013

Revised: 11 February 2014 - Accepted: 13 February 2014 - Published: 7 April 2014

\begin{abstract}
With an extension of $>40 \mathrm{~km}^{2}$ the recently discovered Campeche cold-water coral province located at the northeastern rim of the Campeche Bank in the southern Gulf of Mexico belongs to the largest coherent cold-water coral areas discovered so far. The Campeche province consists of numerous 20-40 m-high elongated coral mounds that are developed in intermediate water depths of 500 to $600 \mathrm{~m}$. The mounds are colonized by a vivid cold-water coral ecosystem that covers the upper flanks and summits. The rich coral community is dominated by the framework-building Scleractinia Enallopsammia profunda and Lophelia pertusa, while the associated benthic megafauna shows a rather scarce occurrence. The recent environmental setting is characterized by a high surface water production caused by a local upwelling center and a dynamic bottom-water regime comprising vigorous bottom currents, obvious temporal variability, and strong density contrasts, which all together provide optimal conditions for the growth of cold-water corals. This setting - potentially supported by the diel vertical migration of zooplankton in the Campeche area - controls the delivering of food particles to the corals. The Campeche cold-water coral province is, thus, an excellent example highlighting the
\end{abstract}

importance of the oceanographic setting in securing the food supply for the development of large and vivid cold-water coral ecosystems.

\section{Introduction}

The last decade has witnessed a tremendous progress in our knowledge about "framework-building cold-water corals" (CWC) as their role as ecosystem engineers creating highly diverse ecosystems in water depths far beyond the shelf edge is becoming more and more obvious (Roberts et al., 2009). The biodiversity associated with these ecosystems may be comparable to that found in tropical coral reefs (Roberts et al., 2006), and they occur almost worldwide except for the highest latitudes (Davies and Guinotte, 2011). The availability of advanced deep-sea technologies (e.g., remotely operated vehicles) greatly supported the discovery and investigation of large, thriving and (so far) unknown CWC ecosystems in remote places. Successful studies such as those performed off Mauritania (Colman et al., 2005), off Angola (Le Guilloux et al., 2009), and in various parts of the Mediterranean 
Sea (Freiwald et al., 2009; Orejas et al., 2009; Fink et al., 2013; Gori et al., 2013) demonstrate the potential use of these technologies for future discoveries.

With their rigid carbonate skeletons that can persist over geological timescales CWC shape the sea floor by creating large three-dimensional structures, e.g., $>300 \mathrm{~m}$-high coral carbonate mounds along the Irish margin (e.g., Kenyon et al., 2003; Mienis et al., 2007) reaching back to Pliocene times ( $~ 2.6 \mathrm{Ma}$; Kano et al., 2007) and $>100 \mathrm{~km}^{2}$-large reef structures off Norway (Fosså et al., 2005) formed during the Holocene (e.g., López Correa et al., 2012). These structures consist of a mixture of coral skeletons, the skeletal remains of the coral-associated megafaunal community, and pelagic or hemipelagic sediments that can serve as paleoenvironmental archives allowing to reconstruct the long-term development of the CWC ecosystems (e.g., Dorschel et al., 2005; Frank et al., 2009; Titschack et al., 2009; Wienberg et al., 2009; Eisele et al., 2011; Fink et al., 2012; López Correa et al., 2012; Douarin et al., 2013; Thierens et al., 2013).

The scleractinian coral Lophelia pertusa is among the most common and most widespread CWC species worldwide and is particularly abundant in the eastern North Atlantic (Davies and Guinotte, 2011). This species withstands a rather wide range of physicochemical conditions (see summary in Davies et al., 2008), a fact that explains its almost global distribution at depths between a few tens of meters to over $2000 \mathrm{~m}$ (Freiwald and Roberts, 2005). Another critical factor controlling its distribution is sufficient food supply that is commonly driven by the interplay of surface water productivity and the local nature of the bottom current regime (e.g., currents, stratification, internal waves and tides) delivering food particles to the CWC (Duineveld et al., 2004, 2007; White et al., 2005). Paleoenvironmental studies revealed that food supply often is the decisive factor triggering on- or offsets of coral growth in a given setting (e.g., Dorschel et al., 2005; Wienberg et al., 2010; Eisele et al., 2011; Fink et al., 2013).

In addition to the CWC hotspot in the eastern North Atlantic, L. pertusa also contributes to numerous coral mound structures in the western North Atlantic along the continental margin from North Carolina (Ross and Nizinski, 2007), along the Florida-Hatteras slope (Paull et al., 2010), and The Bahamas to the Florida Straits (e.g., Neumann et al., 1977; Mullins et al., 1981; Grasmueck et al., 2006; Correa et al., 2012a, b). Further west in the Gulf of Mexico, L. pertusa appears to be more scattered, forming isolated mound-like structures along the west Florida slope (Newton et al., 1987; Hübscher et al., 2010) and in the northern Gulf of Mexico (Moore and Bullis, 1960; Schroeder, 2002; Reed et al., 2006; Cordes et al., 2008; Becker et al., 2009; Davies et al., 2010). Summarizing the current knowledge, Mienis et al. (2012) conclude that within the Gulf of Mexico CWC mound structures have been rarely found, except on the west Florida slope and in the Viosca Knoll area (Fig. 1). The latter area has been considered the most extensive Lophelia habitat found

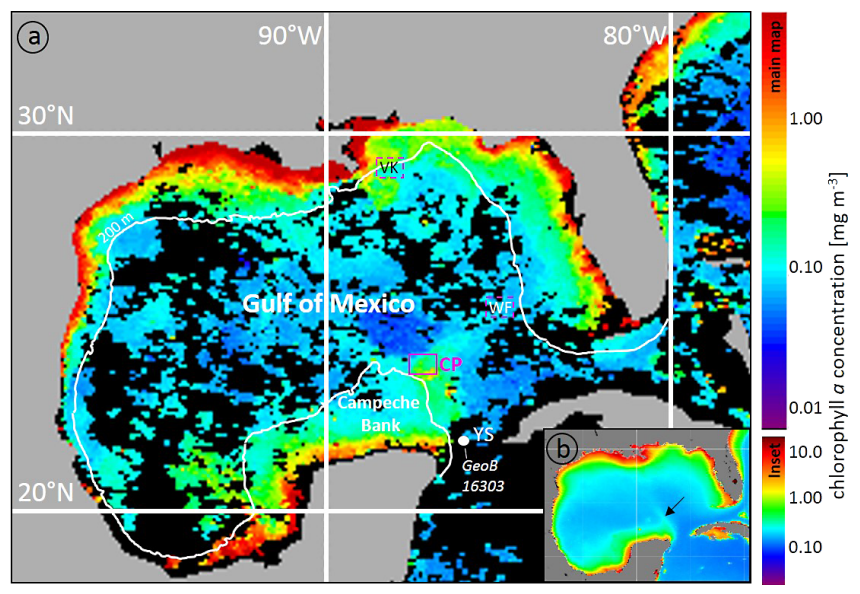

Fig. 1. SEAWIFS satellite ocean color data transferred into chlorophyll $a$ concentrations for the Gulf of Mexico (source: http://oceancolor.gsfc.nasa.gov). (a) The map refers to an 8-day composite representing the period 22-29 September 2010. Black indicates data gaps. The Campeche cold-water coral province (CP) is influenced by increased productivity probably forced by local upwelling at the northeastern rim of the Campeche Bank (Molinari and Morrison, 1988). The white dot in the Yucatan Strait (YS) indicates CTD station GeoB 16303-1. The white line marks the $200 \mathrm{~m}$ isobath within the Gulf of Mexico. VK: Viosca Knoll cold-water coral setting (e.g., Brooke and Schroeder, 2007); WF: west Florida cold-water coral mounds (Newton et al., 1987). (b) The inset shows the same data as a composite for the entire SEAWIFS mission (4 September 1997 to 30 November 2010). The black arrow indicates the area of the Campeche cold-water coral province that is located in a region marked by a long-term enhanced productivity.

so far in this region (Brooke and Schroeder, 2007; Davies et al., 2010) probably as a consequence of enhanced productivity driven by nutrient-enriched Mississippi River outflow (Wawrik and Paul, 2004). Apart from the Campeche Bank, the southern Gulf of Mexico is generally characterized by meager planktonic biomass along the Mexican slope mirroring the low-productivity Caribbean water that enters the Gulf of Mexico through the Yucatan Strait (Wei et al., 2012).

In this paper, we document for the first time build-ups at the sea floor formed by framework-building scleractinian corals on the slope of the Mexican Campeche Bank, southern Gulf of Mexico. These build-ups are mainly formed by Enallopsammia profunda-Lophelia pertusa communities. This finding was unexpected as available data from a few dredge haul stations only described the occurrence of the scleractinian CWC Madrepora oculata along the margin of the Campeche Bank, north of the Mexican Yucatan Peninsula (Cairns, 1979; Schroeder et al., 2005). Only in 2010 was more detailed information provided, when hydroacoustic surveys revealed "mound-like" structures between 500 and $600 \mathrm{~m}$ water depth along the margin of the bank (Hübscher et al., 2010). Without any groundtruthing being available at 
that time, it only has been speculated that these structures might be CWC mounds (Hübscher et al., 2010).

This region was revisited in 2012 and extensive field data (bathymetry, hydrography, and video observations) revealed the existence of a large thriving CWC ecosystem, which is the focus of this paper. This hitherto unknown CWC site is here termed the "Campeche CWC province". The scope of the present study is to describe this extensive $\left(>40 \mathrm{~km}^{2}\right)$ CWC province with respect to morphology, the megafaunal community, and the oceanographic setting and to put it into a larger framework analyzing the overall forcing factors controlling its development.

\section{Regional setting}

The Campeche Bank is a large shelf area extending approximately $200 \mathrm{~km}$ northward from the Mexican Yucatan Peninsula into the Gulf of Mexico (Fig. 1). The Gulf of Mexico is a largely oligotrophic basin with enhanced productivity only along the continental shelves (Müller-Karger et al., 1991), where seasonal coastal upwelling provides additional nutrients to the surface waters (Zavala-Hidalgo et al., 2006). A major source of nutrients is the Mississippi plume fertilizing the northeastern shelves of the Gulf with enhanced productivity partly extending over the continental slope (Wawrik and Paul, 2004). The enhanced productivity triggered by the Mississippi plume most likely plays an important role in sustaining CWC populations along the Louisiana and Florida continental slopes (e.g., Newton et al., 1987; Schroeder, 2002; Fig. 1).

Apart from the typical coastal upwelling, another upwelling regime has been described further offshore along the eastern margin of the Campeche Bank (Merino, 1997). As the curl of the prevailing wind stress is not likely to induce upwelling along the eastern Yucatan slope, the upwelling observed there is probably caused by bottom friction or other topographical effects (Merino, 1997). Nevertheless, the advection of nutrients into the photic zone (although rarely to the sea surface; Merino, 1997) induces very high productivity reaching a peak in September (Zavala-Hidalgo et al., 2006) when sites near the Campeche CWC province appear prominently in satellite-based productivity maps (Fig. 1).

Along its eastern edge the Campeche Bank borders the Yucatan Strait that forms the main passage connecting the Caribbean Sea and the Gulf of Mexico through which the Yucatan Current transports $\sim 24 \mathrm{~Sv}$ from south to north (Sheinbaum et al., 2002). According to Merino (1997) three main water masses comprise the water column there. Salinity and temperature increase together from the Antarctic Intermediate Water (AAIW, $7^{\circ} \mathrm{C}$, salinity 34.9) in the deep towards the salinity maximum of the Subtropical Intermediate Water (STUW, $23^{\circ} \mathrm{C}$, salinity 36.8 ) at $\sim 150 \mathrm{~m}$ depth. Further above, temperature rises and salinity declines until from $50 \mathrm{~m}$ to the surface both parameters remain relatively constant
(26-27.5 ${ }^{\circ} \mathrm{C}$, salinity $\left.<36.4\right)$, representing the Caribbean Surface Water (CSW). At depths greater than $\sim 650 \mathrm{~m}$, the Yucatan and Cuban countercurrents transport water southward while being confined to the western, Mexican side and to the eastern, Cuban side of the Yucatan Strait, respectively (Sheinbaum et al., 2002).

With respect to the strength of the bottom current regime, the best information is provided by mooring data obtained slightly further south in the Yucatan Strait $\left(\sim 21.5^{\circ} \mathrm{N}\right.$; e.g., Sheinbaum et al., 2002). Along a W-E transect through the area, the mean northward current velocities at the western margin decrease rapidly from almost $100 \mathrm{~cm} \mathrm{~s}^{-1}$ at the surface to $<10 \mathrm{~cm} \mathrm{~s}^{-1}$ at $200 \mathrm{~m}$ water depth. However, at the depth of the Campeche CWC province $(\sim 550 \mathrm{~m})$ the bottom current velocities in the Yucatan Strait increase again to $>10 \mathrm{~cm} \mathrm{~s}^{-1}$ (Sheinbaum et al., 2002).

\section{Methods}

All data presented here were collected during expedition MSM 20-4 with the German R/V Maria S. Merian in spring 2012 (Hebbeln et al., 2012). They include hydroacoustic measurements, water column studies, and seabed ROV video observation (see Table 1 and Fig. 2 for relevant site information). Instrument specifications and applied settings for the hydroacoustic measurements are described in detail in Hebbeln et al. (2012). For all hydroacoustic measurements introduced below, the essential sound velocity profile through the water column was obtained from two CTD casts in (GeoB 16305-1) and close to (GeoB 16303-1) the working area (Figs. 1 and 2, Table 1).

\subsection{Hydroacoustic measurements}

\subsubsection{Multibeam echosounder (MBES)}

Seabed mapping was performed using a KONGSBERG EM1002 multibeam echosounder system (MBES) operating at a frequency of $95 \mathrm{kHz}$. The EM1002 emitted 111 beams per ping, covered a depth range of 2 to $1000 \mathrm{~m}$ and achieved a high depth resolution of $2-8 \mathrm{~cm}$, depending on the pulse length $(0.2-2 \mathrm{~ms})$. Achievable swath width on a flat bottom was up to 5 times the water depth dependent on the character of the seafloor. Spatial integrity of the mapping data were achieved by combining the ship's SEAPATH 200 inertial navigation system (INS) including differential global positioning system (DGPS) information with motion data (roll, pitch, heave) provided by the motion reference unit (MRU) 5. The open-source software package MB-System v.5.3.1 (Caress and Chayes, 1996) and the Generic Mapping Tool (GMT) v.4.3.1 (Wessel and Smith, 1998) were used for bathymetric data processing, editing and evaluation. ESRI ArcGIS v.10 was used to create maps (grid cell size: $10 \mathrm{~m}$ ) and a sustainable spatial data management. 


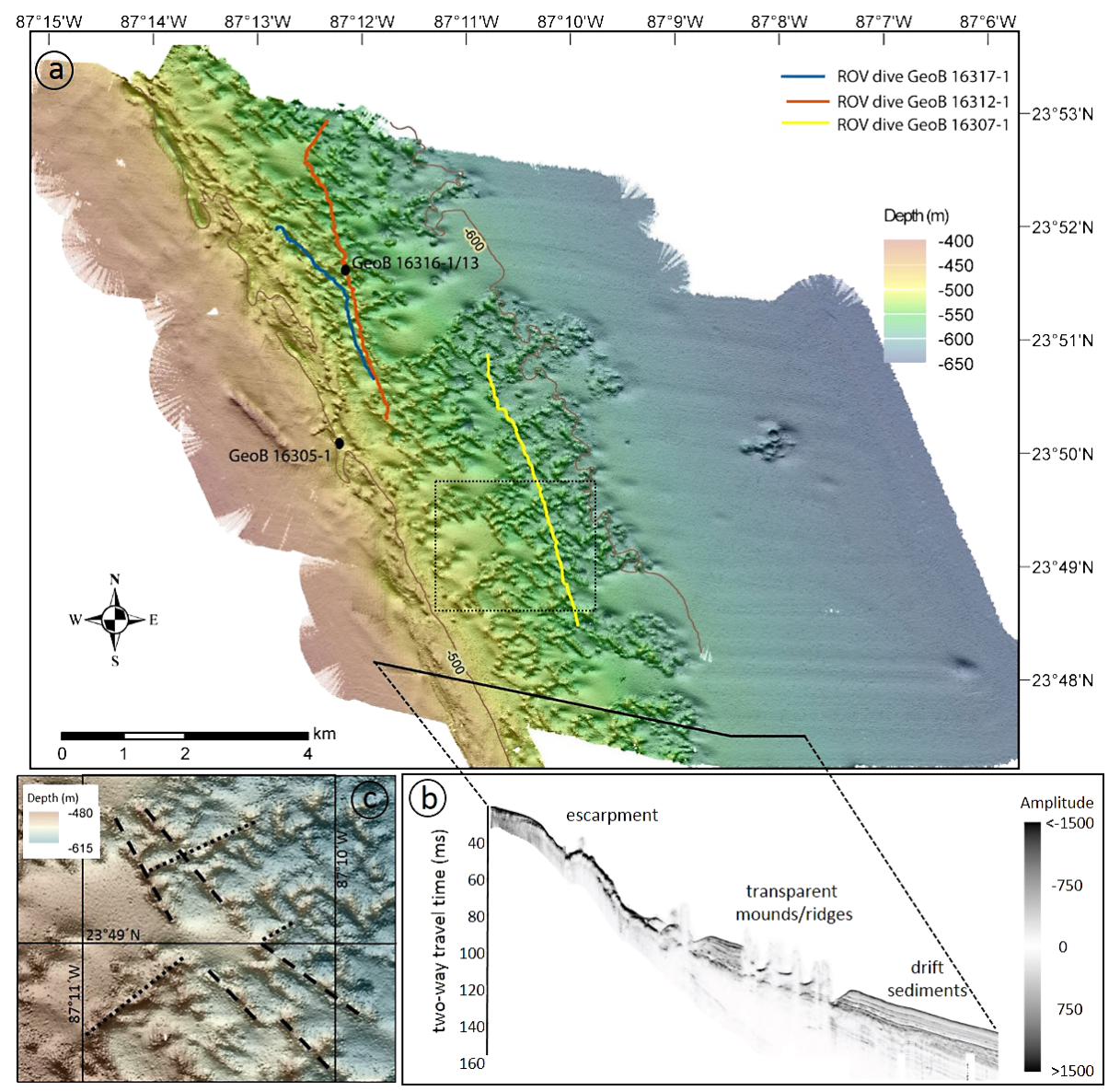

Fig. 2. Overview on the Campeche cold-water coral province (for location see Fig. 1). (a) Detailed bathymetric map showing the eastern margin of the Campeche Bank comprising the Campeche cold-water coral province revealing numerous individual elongated coral mounds located mainly between 500 and $600 \mathrm{~m}$ water depth. Indicated are CTD sites (black dots) and ROV dive tracks (colored lines; GeoB station numbers are indicated) conducted during R/V Maria S. Merian cruise MSM 20-4 (for detailed site information see Table 1). (b) PARASOUND profile crossing the slope and highlighting the main morphological units. (c) High-resolution view on some of the elongated coral mounds (for position see dotted rectangle in a), with the dominant northwesterly directions marked by dashed lines and with the sub-dominant northeasterly directions marked by the dotted lines.

\subsubsection{Acoustic Doppler current profiler (ADCP)}

Current velocity and direction, and backscatter data through the water column were measured with an RDI Ocean Surveyor acoustic Doppler current profiler (ADCP) operating at a frequency of $75 \mathrm{kHz}$. Data were acquired using the RDI software VMDAS (Vessel-Mount Data Acquisition) using 128 depth bins of $5 \mathrm{~m}$ bin size. Backscatter data were corrected for beam spreading and water absorption (Deines, 1999). For the backscatter data set presented in this study, a constant water absorption coefficient of $0.0272 \mathrm{~dB} \mathrm{~m}^{-1}$ was used (Schulkin and Marsh, 1962). Due to the simultaneous deployment of several hydroacoustic devices, backscatter and current velocity data were affected by acoustic interference, which was removed using appropriate filters. Backscatter data close to the seafloor were biased by side-lobe interferences and not used for interpretation. ADCP data are presented as a stationary $12 \mathrm{~h}$ record collected at site GeoB 16316 (Fig. 2, Table 1).

\subsection{ROV video observation and sampling}

Three video surveys (GeoB 16307-1, GeoB 16312-1, GeoB 16317-1; Table 1, Fig. 2) were conducted with the ROV Cherokee (Sub-Atlantic, Aberdeen, Scotland; operated by MARUM, Bremen, Germany) crossing several CWC mounds along the Campeche margin. The ship-based IXSEA global acoustic positioning system (GAPS) coupled with the ship's DGPS provided an absolute positioning accuracy within $1-2 \%$ of the slant range. The ROV was equipped with a hydraulic manipulator system for sampling purposes, four video cameras including a color video zoom camera for detailed seafloor observation and a digital still camera. The cameras were equipped with two lasers for object size measurements on the seabed; laser scaling was adjusted to 
Table 1. Metadata of CTD casts and ROV Cherokee video surveys conducted at the Campeche cold-water coral province during R/V Maria S. Merian cruise MSM 20-4. Abbreviations: WD: water depth.

\begin{tabular}{|c|c|c|c|c|c|c|c|c|}
\hline $\begin{array}{l}\text { Station } \\
\text { [GeoB-No.] }\end{array}$ & Gear & & $\begin{array}{l}\text { Date } \\
{[2012]}\end{array}$ & $\begin{array}{l}\text { UTC } \\
\text { [hh:mm] }\end{array}$ & $\begin{array}{l}\text { Latitude } \\
{[\mathrm{N}]}\end{array}$ & $\begin{array}{l}\text { Longitude } \\
{[\mathrm{W}]}\end{array}$ & $\begin{array}{l}\text { WD } \\
{[\mathrm{m}]}\end{array}$ & Remark \\
\hline $16303-1$ & CTD & & $21 \mathrm{March}$ & $14: 59$ & $22^{\circ} 00.98^{\prime}$ & $86^{\circ} 02.95^{\prime}$ & 1246 & Sound velocity profile \\
\hline $16305-1$ & CTD & & $22 \mathrm{March}$ & $05: 21$ & $23^{\circ} 49.87^{\prime}$ & $87^{\circ} 12.27^{\prime}$ & 506 & Sound velocity profile \\
\hline \multirow[t]{2}{*}{$16316-1$ to $16316-13$} & \multirow[t]{2}{*}{ Yoyo CTD } & Start: & 24 March & 00:20 & $23^{\circ} 51.51^{\prime}$ & $87^{\circ} 12.12^{\prime}$ & 576 & \multirow{2}{*}{$\begin{array}{l}\text { Hourly casts over } \sim 12 \mathrm{~h} ; \\
\text { ADCP data were recorded } \\
\text { simultaneously over } \sim 13 \mathrm{~h}\end{array}$} \\
\hline & & End: & $24 \mathrm{March}$ & 12:01 & $23^{\circ} 51.52^{\prime}$ & $87^{\circ} 12.13^{\prime}$ & 558 & \\
\hline \multirow{2}{*}{$16307-1$} & \multirow{2}{*}{ ROV } & Start: & 22 March & $13: 51$ & $23^{\circ} 40.83^{\prime}$ & $87^{\circ} 10.03^{\prime}$ & 547 & \multirow{2}{*}{ Video observation } \\
\hline & & End: & 22 March & $16: 20$ & $23^{\circ} 50.49^{\prime}$ & $87^{\circ} 10.71^{\prime}$ & 577 & \\
\hline \multirow{2}{*}{$16312-1$} & \multirow{2}{*}{ ROV } & Start: & 23 March & $14: 31$ & $23^{\circ} 50.35^{\prime}$ & $87^{\circ} 11.76^{\prime}$ & 523 & \multirow{2}{*}{ Video observation } \\
\hline & & End: & 23 March & $18: 31$ & $23^{\circ} 52.52^{\prime}$ & $87^{\circ} 12.49^{\prime}$ & 531 & \\
\hline \multirow{2}{*}{$16317-1$} & \multirow{2}{*}{ ROV } & Start: & $24 \mathrm{March}$ & $13: 37$ & $23^{\circ} 51.12^{\prime}$ & $87^{\circ} 12.53^{\prime}$ & 555 & \multirow{2}{*}{ Video observation } \\
\hline & & End: & 24 March & $15: 02$ & $23^{\circ} 51.77^{\prime}$ & $87^{\circ} 12.16^{\prime}$ & 556 & \\
\hline
\end{tabular}

$11.5 \mathrm{~cm}$ in a horizontal direction. All video and still-image data were digitally stored. Navigational data (ship, ROV), video recordings, and still images are all time-referenced. With the manipulator of the ROV several coral samples were collected to assess the phenotypes of the different CWC species.

\subsection{Water column analyses}

To determine the physical parameters of the water masses in the area of the Campeche CWC province and to trace their variability, CTD measurements were performed as a Yoyo CTD comprising 13 individual casts taken within $12 \mathrm{~h}$ at station GeoB 16316 (Fig. 2, Table 1). The CTD measurements of the water column down to a maximum water depth of $1246 \mathrm{~m}$ were conducted using a SEABIRD "SBE 9 plus" underwater unit and a SEABIRD "SBE 11 plus V2" deck unit. The vertical profile over the water column provided standard data for conductivity, temperature, pressure, and dissolved oxygen. Conductivity and temperature data were used to compute salinity (with the latter being presented here unitless). The data presented here all refer to the downcast of the individual CTD deployments.

\section{Results}

\subsection{Morphology and dimensions of the Campeche cold-water coral province}

The hydroacoustic mapping encompasses an area of $180 \mathrm{~km}^{2}$ along the northeastern slope of the Campeche Bank and displays three distinct topographical features (Fig. 2). The western part of the map shows an extensive more or less plain area at $\sim 440 \mathrm{~m}$ water depth. A NNW-SSE orientated and $\sim 40 \mathrm{~m}$-high escarpment separates this rather shallow and plain area from a gently dipping slope to the east, which covers the water depths between 480 and $600 \mathrm{~m}$. Further downslope below $\sim 600 \mathrm{~m}$ water depth, the slope is followed by a more gently dipping area which comprises smooth sediment of a major drift sediment body (Hübscher et al., 2010). The first 3-5 km of the dipping slope east of the edge are covered by linear and steep-sided elongated mounds between 500 and $600 \mathrm{~m}$ water depth. This belt of parallel elongated mounds is situated between the escarpment and the continuous drift deposit, with a few stratified sediment bodies also occurring between the mounds. Both the mounds and the sediment drift overlay a regional truncation surface (Fig. 2b; Hübscher et al., 2010).

The mounds have average heights between 20 and $40 \mathrm{~m}$ but can even reach heights of up to $50 \mathrm{~m}$. They vary in length from a few tens of meters to $>1000 \mathrm{~m}$, and trend in two directions. The dominant direction is NW-SE and the second one NE-SW (Fig. 2c). In many cases both directions merge, thereby forming $\mathrm{V}$-shaped elongated mounds pointing with the tip to the WNW. ROV-based video observations reveal that the morphology of these mounds is mostly rather steep with estimated angles of up to $30^{\circ}$ (e.g., Fig. 3e). These elongated mounds are often aligned by a moat towards the next mound (Fig. 2). In addition, on some of the mound flanks exhumed carbonate crusts with irregular upper and lower surfaces have been observed (Fig. 3h). As the video observations clearly indicate that these mounds are covered by a vivid CWC ecosystem (Figs. 3a, b and 4a, b), the entire structure is termed here the Campeche CWC province. The minimum extension of the Campeche CWC province is $40 \mathrm{~km}^{2}$; however, most likely this CWC province is even larger, as it still has a significant width at the northern and southern boundaries of the mapped area (Fig. 2). Thus, the ultimate northern and southern boundaries of the Campeche CWC province still need to be verified. 

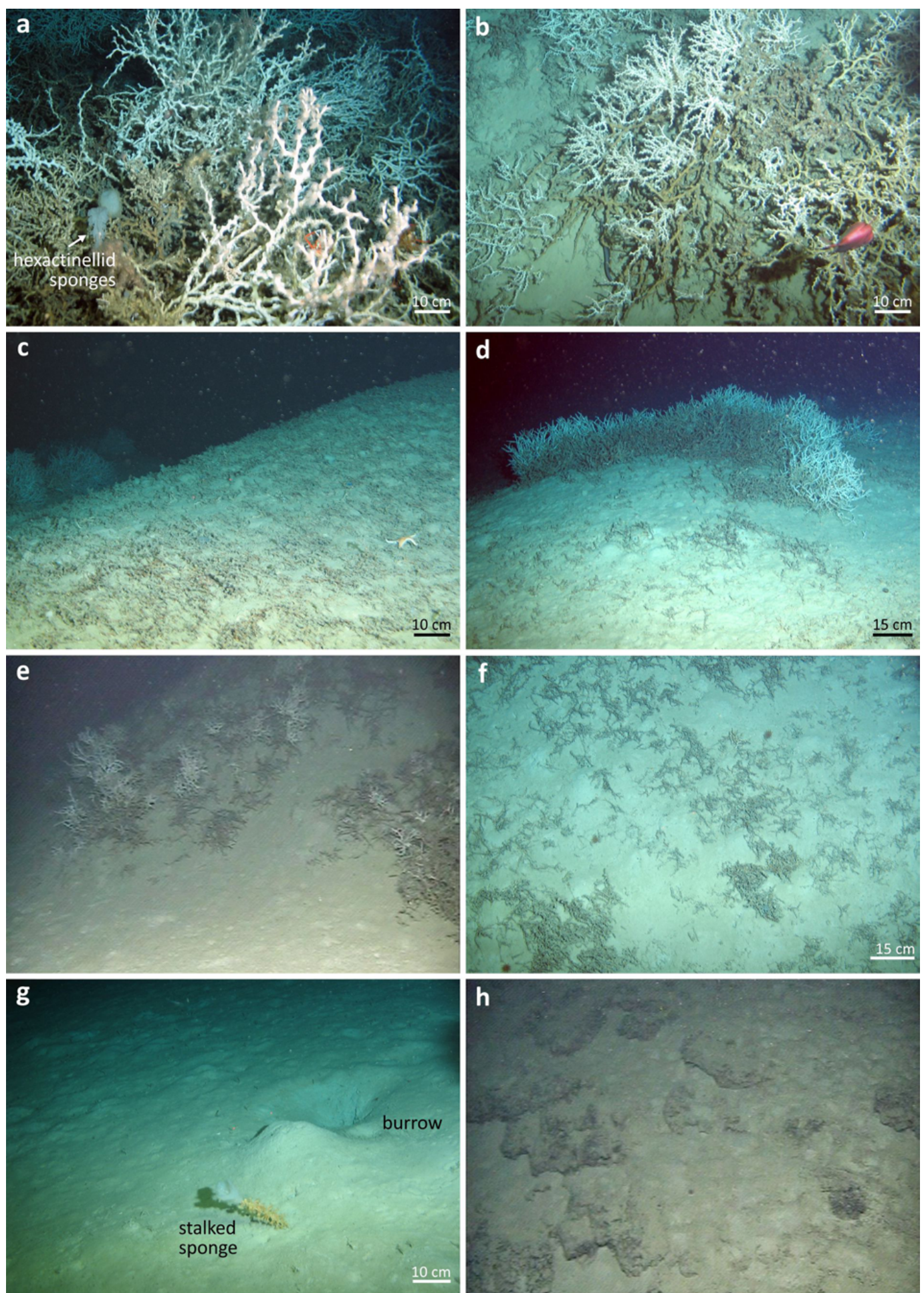

Fig. 3. ROV images showing the variety of facies types observed for the Campeche cold-water coral province (images copyright MARUM, Bremen, ROV Cherokee team). (a) Coral mound summit: dense colonies of Lophelia pertusa - note Hexactinellid sponges (Aphrocallistes sp.) and squat lobster; (b) current-exposed coral mound flank: ensemble of the fragile Enallopsammia profunda and the brachycephala morphotype of L. pertusa; (c) mound flank packed with dead coral framework; (d) arcuate E. profunda thicket on a low-relief mound; (e) sudden facies change from flat soft sediment plain to steeply inclined coral mound flank; (f) lower coral mound flank: dispersed fragments of E. profunda; (g) intermound area: strongly bioturbated soft sediment - note stalked sponge (Hyalonema sp.) colonized by actiniarians; and (h) occasionally observed outcropping carbonate crusts. 


\subsection{The Campeche cold-water coral ecosystem}

Observations during three ROV dives that cross several mounds of the Campeche CWC province reveal the composition of the structure-forming CWC and their associated megafaunal community. The dive tracks of the video surveys had an NNW-SSE orientation in water depths ranging 510 $580 \mathrm{~m}$ (Fig. 2). All mounds studied are colonized by colonial scleractinians representing Enallopsammia profundaLophelia pertusa communities (Figs. 3 and 4), whereas the flat seabed between the mounds consists of pelagic unconsolidated mud enriched by globigerinid foraminifers and thecosomatous gastropods, locally admixed with patches of coral rubble and mollusk shell hash (see detailed description of collected sediment samples in Hebbeln et al. (2012)). These intermound areas are strongly bioturbated as indicated by widespread lebensspuren and burrows (Fig. 3g).

Coral colonization, coral density and coral species distribution show a clear zonation related to current exposure and position on the mound flank. In general, living corals occur at the highest parts of the mounds, followed downslope by a zone of coral rubble and by plain soft sediments in the lower parts of the mounds and in the areas between the mounds (Fig. 3). However, on some steeply inclined mounds (up to $30^{\circ}$ ), coral colonization starts already at the base of their current-exposed side (SSE), thereby generating a sharp change of sedimentary facies from pelagic muds to a living CWC ecosystem. On less steep mounds live coral colonies start to appear halfway upslope the current-exposed flank, or the mound flanks are entirely covered by a dead and collapsed coral framework or coral rubble with only few live coral colonies in between. For both types of mounds, corals fade off halfway along the leeward flanks of the mounds. Overall, the density of coral framework and the proportion of live coral colonies become progressively higher towards the summit, where they can form very dense coral thickets up to $60 \mathrm{~cm}$ thick. The mound flanks are dominated by E. profunda, whereas $L$. pertusa becomes increasingly abundant, if not dominant on the summits.

The dendroid E. profunda colonies display an open-spaced growth habit with individual colony branches pointing in all directions (Fig. 4a and b). This growth habit results in a loose mesh of coral framework, thus facilitating framework disintegration of individual branches into stick-like fragments. Colony heights vary from 20 to $60 \mathrm{~cm}$; thus only the upper $10-15 \mathrm{~cm}$ of a colony yields live coral polyps and translucent tissue. Lophelia pertusa also constructs an open-spaced coral framework. However, secondary fusion between adjacent coral branches is a very common feature, thus increasing the structural integrity of the entire framework considerably in comparison to E. profunda. The branches of $L$. pertusa are strongly calcified and slender with individual corallite lengths of $2.5-3.5 \mathrm{~cm}$ and calicular diameters of $0.5-0.8 \mathrm{~cm}$. This phenotype has been described as forma gracilis by Duncan (1873) and is in contrast to the stout branches with extremely wide calicular diameters of the brachycephala form (Fig. 4a) described by Moseley (1881) and Cairns (1979). The latter phenotype occurs in low numbers in the Campeche CWC province, but the co-occurrence of the two L. pertusa growth forms is a well-known phenomenon in the northern Gulf of Mexico (Newton et al., 1987; Brooke et al., 2009). The Lophelia framework can attain heights of $50 \mathrm{~cm}$, and the zone of live polyps and translucent tissue coverage stretch over a range of $20-30 \mathrm{~cm}$.

The live coral zone is utilized by the associated community in various ways and differs largely in terms of species composition and richness from the associated community found in the tissue-barren, exposed coral framework beneath. Common organisms observed (although not exclusively) in the live zone are the predatory decapods Bathynectes longispina, Eumunida picta, Chaceon fenneri, Munidopsis sp. and Rochinia crassa and the grazing echinoids Cidaris sp. and Gracilechinus sp. (Fig. 4e). The latter echinoid has been recognized as a corallivore in CWC habitats of the eastern North Atlantic (Stevenson and Rocha, 2013). Other organisms with corallivore affinities in the live coral zone are star fishes of the genus Hippasteria (Mah et al., 2010) and the muricid gastropod Coralliophila richardi (Taviani et al., 2009), which were commonly collected from the live coral zone. Stalkless crinoids have been occasionally observed to take advantage of the elevated and current-exposed position of live coral branches for filtering particles from the water. Indication of probably necrotic epibiosis of live scleractinians by zoanthids and actiniarians in some scleractinian colonies is a common feature and seems to cause local mortality. Polychaetes of the genus Eunice, from which several species are known as symbionts of $L$. pertusa and other colonial CWC (e.g., Buhl-Mortensen and Mortensen, 2004; Mueller et al., 2013), are surprisingly rare in the Campeche CWC province.

Characteristic organisms of the tissue-barren, exposed coral framework are flytrap anemones (probably Actinoscyphia sp.; Fig. 4b), isidid corals (Keratoisis sp.), and solitary scleractinians (Desmophyllum dianthus, Javania cailetti, Stenocyathus vermiformis, Trochopsammia infundibulum). The glass sponge Aphrocallistes sp. was found attached to the coral framework. Apparently the glass sponges are living together with masses of yellow actiniarians (Fig. 4f), thus resembling the recently described symbiotic relationship between the glass sponge Hyalonema sieboldi with the actiniarian Spongiactis japonica (Sanamyan et al., 2012). Common fishes encountered frequently in the coral framework were Helicolenus dactylopterus and Nettenchelys exoria. Gorgonians and antipatharians that are elsewhere common in CWC ecosystems are extremely rare here.

The coral rubble is strongly admixed with unconsolidated pelagic mud, thereby providing small hard-substrate islands within soft sediment. Common megafaunal organisms are large astrorhizid foraminifers, cerianthids, pennatulaceans, stalked glass sponges (Hyalonema sp.), and the 

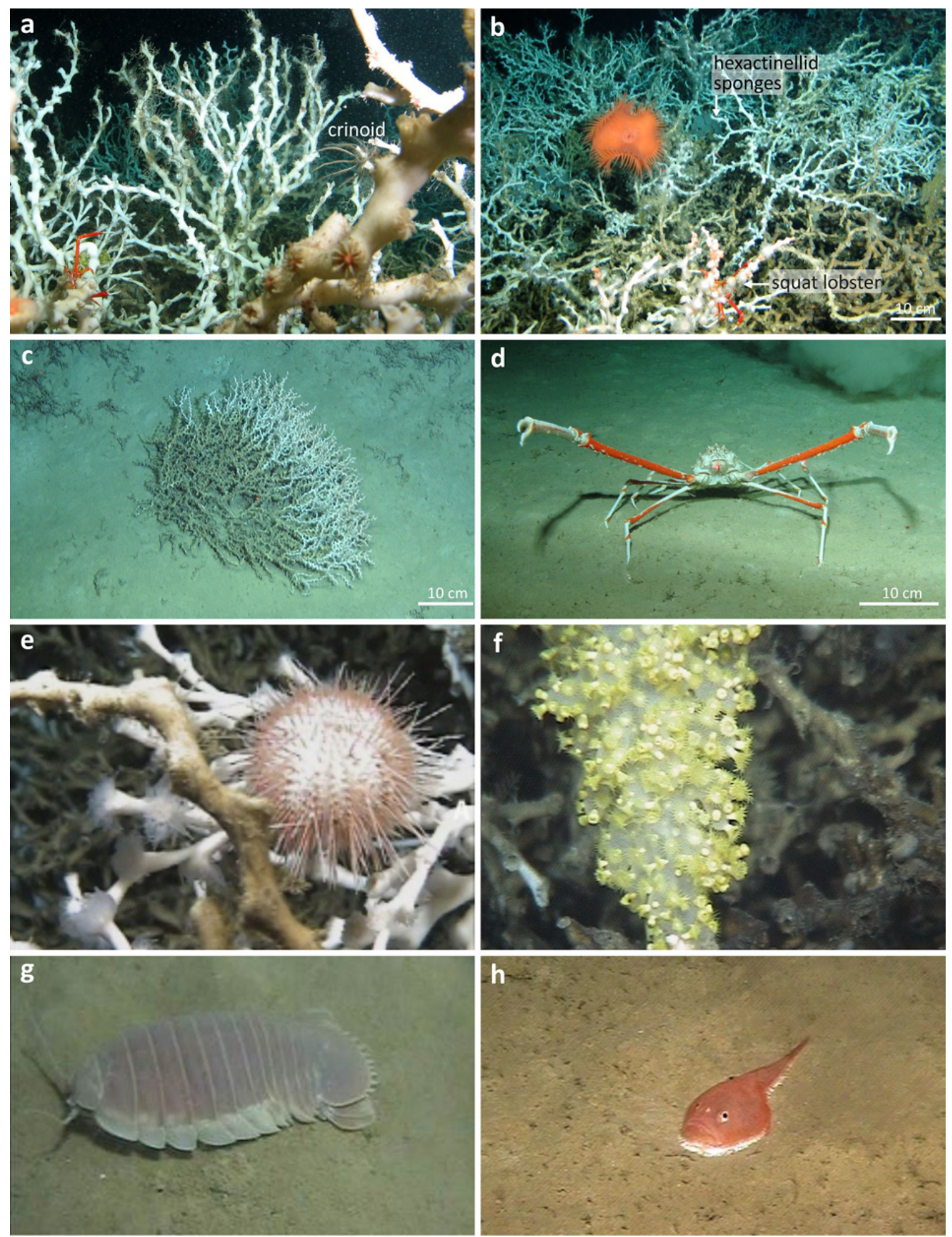

Fig. 4. ROV images showing examples for the megafaunal community present in the Campeche cold-water coral province (images copyright MARUM, Bremen, ROV Cherokee team). (a) Dense colonization of Lophelia pertusa at the coral mound top; (b) flytrap anemone (probably Actinoscyphia sp.) colonizing tissue-barren, exposed coral framework; (c) displaced but still alive colony of Enallopsammia profunda; (d) brachyuran crab Rochinia crassa; (e) grazing of living corals by the echinoid Gracilechinus sp.; (f) glass sponge Aphrocallistes sp. living together with masses of yellow actiniarians; (g) the giant cirolanid isopod Bathynomus giganteus; and (h) the anglerfish Chaunax suttkusi commonly spotted near the coral mounds resting on the seabed.

common decapods (same as in the live zone) and shrimps. Amongst the mobile organisms, the giant isopod crustacean Bathynomus giganteus was detected (Fig. 4g). Like in other coral rubble habitats elsewhere in the Gulf of Mexico and in the northern North Atlantic, the anglerfish Chaunax suttkusi (Fig. 4h), was commonly spotted near the coral mounds resting on the seabed (Caruso et al., 2007). Other common fishes observed in the coral rubble and pelagic mud areas 


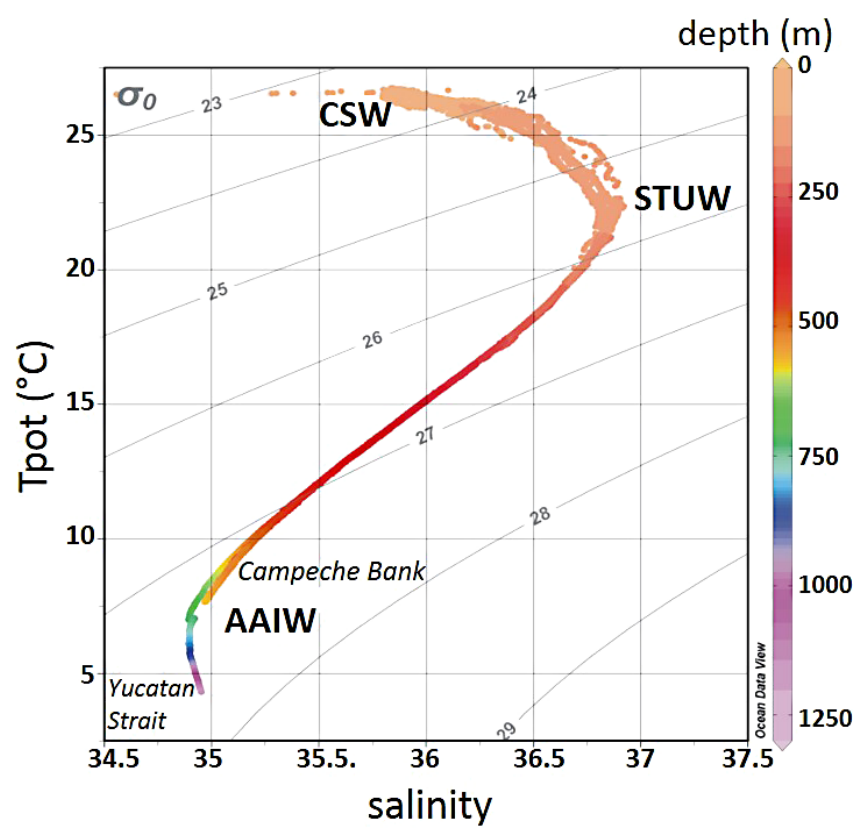

Fig. 5. Water mass structure in the Yucatan Strait (GeoB 16303-1) and in the Campeche cold-water coral province (GeoB 16316-1 to 16, Yoyo CTD station; see Table 1). Shown is a temperature-salinity plot; temperature is displayed as potential temperature $\left(T_{\text {pot }}\right)$, grey lines indicate levels of isodensity $\left(\sigma_{\Theta}\right)$ in $\mathrm{kg} \mathrm{m}^{-3}$ (plotted using Ocean Data View v.4.5.1; http://odv.awi.de; Schlitzer, 2012). Abbreviations: CSW: Caribbean Surface Water; STUW: Subtropical Intermediate Water; AAIW: Antarctic Intermediate Water.

are Chlorophthalmus agassizi, Laemonema sp., Nezumia sp., Phycidae and Rajidae.

\subsection{Water column structure/dynamics}

The CTD measurements allow the identification of the most important regional water masses, based on temperature (potential temperature) and mainly on salinity data (Fig. 5). The uppermost $\sim 80 \mathrm{~m}$ of the water column are characterized by water with salinities of $<36.4$, which is indicative of the presence of the CSW. The salinity maximum $(\sim 36.8)$ between 100 and $160 \mathrm{~m}$ water depth is characteristic for the STUW. At $540 \mathrm{~m}$ water depth salinity drops below 35.0, marking the presence of AAIW. In the depth range where living CWC have been observed (520 to $580 \mathrm{~m}$ ) temperatures range $7.5-9.5^{\circ} \mathrm{C}$ and salinities $34.9-35.1$. Dissolved oxygen contents vary between 2.74 and $2.8 \mathrm{~mL} \mathrm{~L}^{-1}$.

The Yoyo CTD station (GeoB 16316) consisting of 13 individual, hourly taken casts reveal small but significant variations also in the deepest part of the water column just above the Campeche CWC province (Fig. 6): for example, at $519 \mathrm{~m}$ water depth the temperature varies by almost $1^{\circ} \mathrm{C}$ up to three times over the $12 \mathrm{~h}$ measuring period (Fig. $6 \mathrm{c}$ ). These temperature changes are also reflected in the depth position of individual isotherms $\left(8\right.$ to $9.5^{\circ} \mathrm{C}$, Fig. $\left.6 \mathrm{~b}\right)$. They fluctuate vertically by up to $20 \mathrm{~m}$, thereby reflecting the same temporal forcing as the temperatures at $519 \mathrm{~m}$ depth. Along with these temperature changes a distinct density gradient induced by temperature and salinity changes, almost reaching $0.7^{\circ} \mathrm{C}$ and 0.07 , respectively, over a $10 \mathrm{~m}$ depth interval (Fig. 6d) propagates across the site. With $\sim 0.06 \mathrm{~kg} \mathrm{~m}^{-3}$ per $10 \mathrm{~m}$ depth interval this density gradient is strongest for the lower part of the water column at $525 \mathrm{~m}$ depth and significantly higher than the density gradients between $380 \mathrm{~m}$ and the sea floor that otherwise reach maximum values of $\sim 0.04 \mathrm{~kg} \mathrm{~m}^{-3}$ per $10 \mathrm{~m}$ depth interval (Fig. 6a).

The ADCP data collected over a $13 \mathrm{~h}$ time interval (simultaneously to the Yoyo CTD data; see Table 1) allow distinguishing between three major layers that show some internal (although less pronounced) horizontal structuring (Figs. 7 and 8). Within the upper $130 \mathrm{~m}$ of the water column, the highest current velocities $\left(74-83 \mathrm{~cm} \mathrm{~s}^{-1}\right.$ ) occur together with a high backscatter (94-98 dB). Current directions vary between $322^{\circ}$ and $335^{\circ}$. The second layer between 130 and $460 \mathrm{~m}$ is characterized by continuously decreasing current velocities from 63 to $42 \mathrm{~cm} \mathrm{~s}^{-1}$, again by rather stable current directions similar to the uppermost layer $\left(325^{\circ}\right.$ to $\left.336^{\circ}\right)$, and by low backscatter values $(84-94 \mathrm{~dB})$. The bottom layer $(>460 \mathrm{~m})$ is marked by a significant change in current direction $\left(343^{\circ}\right.$ to $\left.360^{\circ}\right)$ and by the lowest but still strong currents flowing at a rate of 24 to $42 \mathrm{~cm} \mathrm{~s}^{-1}$.

At the beginning of the stationary ADCP record (ca. 00:00 UTC, 24 March 2012) enhanced backscatter signals move upward through the water column towards the sea surface. By the end (ca. 11:30 UTC), similar signals move downward towards the seabed (Fig. 7). Similar observations were made during additional ADCP surveys in the working area during cruise MSM 20-4 (Hebbeln et al., unpublished data). In total, four upward (always at around 0:00 UTC, corresponding to $18: 15$ local "solar" time at $86^{\circ} \mathrm{W}$, i.e., sunset) and two downward movements (always at around 11:30 UTC, corresponding 05:45 local solar time at $86^{\circ} \mathrm{W}$, i.e., sunrise) were observed.

\section{Discussion}

Large CWC-formed seafloor structures have been reported from many regions in the world's oceans (see compilation in Freiwald and Roberts (2005)). In addition to the $>300 \mathrm{~m}$ high CWC mounds off Ireland (Kenyon et al., 2003; Mienis et al., 2007; Dorschel et al., 2010), the extensive reefs off Norway (e.g., Fosså et al., 2005) are the most impressive features. Extending over tens of kilometers (e.g., the Sula Reef, $\sim 14 \times 0.5 \mathrm{~km}$, Freiwald et al., 2002; the Røst Reef, $\sim 40 \times 3 \mathrm{~km}$, Fosså et al., 2005) and reaching up to $\sim 40 \mathrm{~m}$ in height, these reefs generally comprise clusters of individual frameworks rather than a single coalescent structure (Freiwald et al., 2002). The Campeche CWC province shows a similar appearance as it comprises a cluster of individual 

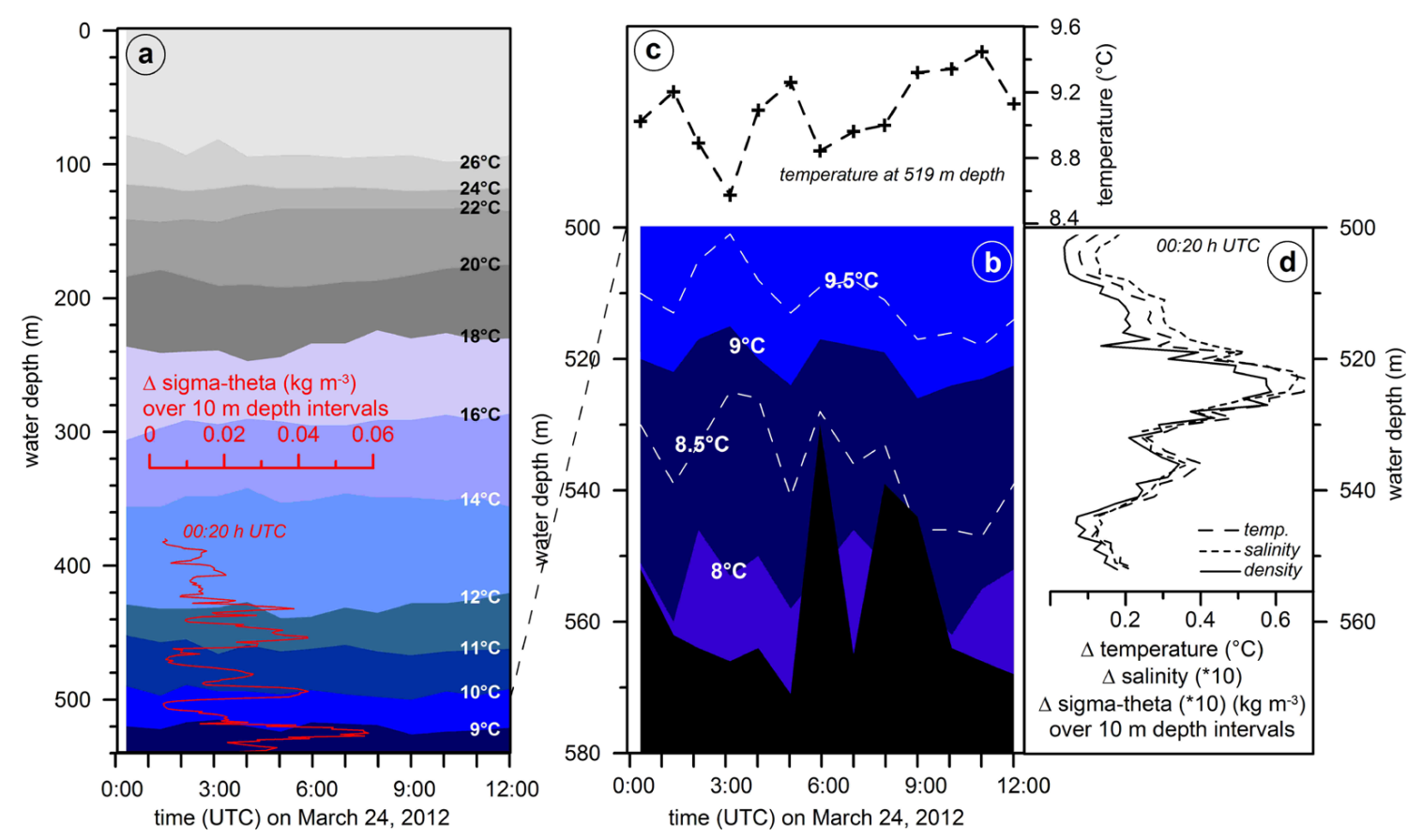

Fig. 6. Hydrological variability derived from the Yoyo CTD station GeoB 16316 (see also Table 1 and Fig. 1). (a) Variability of the temperature distribution in the entire water column over a time interval of $12 \mathrm{~h}$ (comprising 13 individual CTD casts). The red inset shows the density gradient over $10 \mathrm{~m}$ depth intervals for the water column below $380 \mathrm{~m}$ taken from CTD cast GeoB 16316-1 (00:20 UTC). (b) Depth variation of the $8^{\circ} \mathrm{C}$ to $9.5^{\circ} \mathrm{C}$ isotherms in the lower part of the water column $>500 \mathrm{~m}$ water depth over the same time period shows partly vertical movements of $>20 \mathrm{~m}$. Variations in water depth (black denotes the sea floor) are caused by slight movements of the vessel ( $\sim 600 \mathrm{~m} \mathrm{~N}-\mathrm{S}$, $\sim 50 \mathrm{~m} \mathrm{E}-\mathrm{W}$ ) at the Yoyo CTD station (including the crossing of a CWC mound). (c) Water temperature at $519 \mathrm{~m}$ depth measured over the same time period indicates a variability of up to $1^{\circ} \mathrm{C}$. (d) Gradients in temperature, salinity, and density over $10 \mathrm{~m}$ depth intervals. Data were obtained during the individual CTD cast GeoB 16316-1 (00:20 UTC) and reveal particularly strong gradients around 520 m water depth (see also a).

elongated coral mounds rather than a single clearly confined reef structure. The term "province" is used for the present study to describe the CWC mounds along the Campeche Bank following the nomenclature developed for the Irish margin where numerous individual CWC mounds occur clustered in provinces (e.g., White and Dorschel, 2010). With its mapped area of $10 \times 4 \mathrm{~km}$, and most likely further northwestand southeastward extensions, the Campeche CWC province is comparable with the large Norwegian reefs and, thus, belongs to the largest mapped CWC provinces in the world. In addition, the Campeche CWC province represents the most important and extensive flourishing azooxanthellate coral area in the entire Gulf of Mexico discovered so far. The geographically closest CWC province is situated along the Miami Terrace in the Straits of Florida, where $27 \mathrm{~km}^{2}$ of elongated coral mounds are mapped in detail by an autonomous underwater vehicle (Correa et al., 2012a) in an area where earlier studies have reported occurrences of "muddy mounds" and "sand ridges" (Neumann and Ball, 1970).

Whereas the large Irish coral mounds have been accumulated over $>2$ million years (Kano et al., 2007), the Norwegian reefs have been formed only during the last $\sim 10000$ years of the Holocene (e.g., López Correa et al., 2012), when during the last deglaciation the Fennoscandian Ice Sheet retreated beyond the present-day coastline. Large seafloor structures formed by CWC cannot easily be transferred into age, as, for example, the Irish mounds at some point in time changed from a distinct accumulation stage into an almost stagnation stage marked by CWC growth and sediment deposition alternating with extensive periods dominated by erosion (Dorschel et al., 2005; Kano et al., 2007; Eisele et al., 2008). Thus, the average height of the Campeche coral mounds of 20 to $40 \mathrm{~m}$ does not allow for estimating the onset of coral growth in the region. Nevertheless, their size and the collection of a $>10 \mathrm{~m}$-long sediment core containing abundant coral fragments embedded in a matrix of hemipelagic sediments (Hebbeln et al., 2012) reveal that also the Campeche CWC ecosystem has a relevant, although yet not constrained, history.

This sedimentary record adds to the PARASOUND evidence for a "CWC origin" of these mounds. The coral mounds show little to no internal layering and are often transparent (Fig. 2b), which is a common feature for coral carbonate mounds (e.g., Van Rooij et al., 2003; Savini et al., 


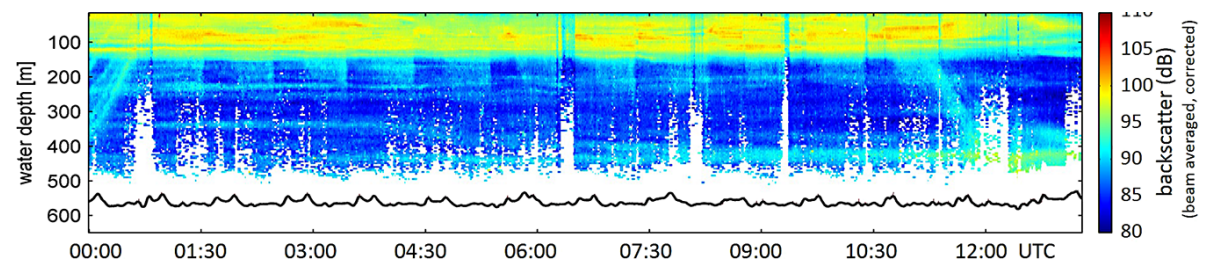

Fig. 7. ADCP-derived backscatter data obtained during a $13 \mathrm{~h}$ stationary measurement from 00:00 to 13:00 UTC on 24 March 2012. ADCP data were recorded simultaneously to the Yoyo CTD station GeoB 16316 (see Table 1). This backscatter record shows the upward (0:000:30 UTC, local sunset) and downward (11:30-12:00 UTC, local sunrise) migration of the zooplankton. Probably biased data close to the seafloor have been omitted.

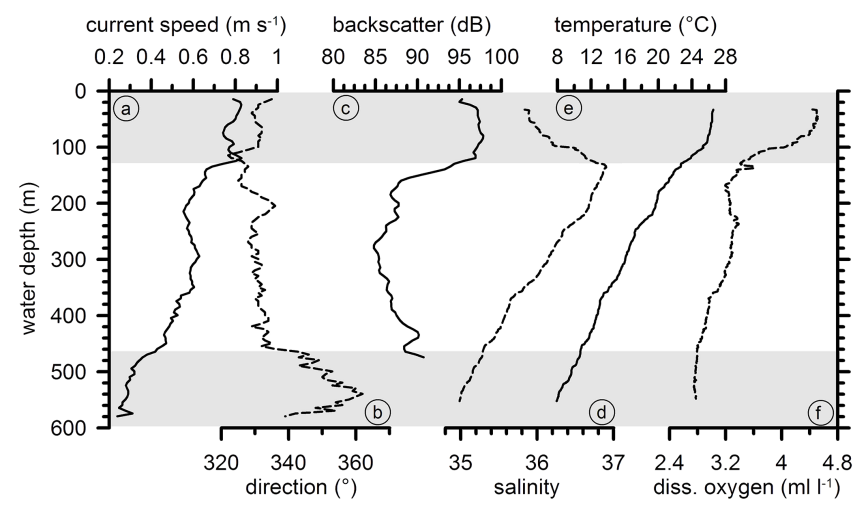

Fig. 8. Water column data for the Yoyo CTD site GeoB 16316. Mean values for (a) current speed, (b) current direction, and (c) backscatter averaged from the $13 \mathrm{~h}$ stationary ADCP measurement. CTD data from cast GeoB 16316-1 for (d) salinity, (e) temperature, and (f) dissolved oxygen. The dashed lines refer to the lower $x$ axes. The grey shadings delineate the different layers of the water column as derived from the ADCP data.

2014). The PARASOUND profile crossing the Campeche CWC province from west to east displays a strong reflection underneath the drift sediment bodies and the CWC mounds developed along the Campeche Bank slope (Hübscher et al., 2010). It is assumed that this continuous strong reflector forms the base of the coral mounds (Hübscher et al., 2010) that might have provided the hardground allowing for the initial coral settlement similar to the erosional unconformity forming the base of the Irish CWC mounds (Van Rooij et al., 2003; Kano et al., 2007).

CWC often form coral mounds that can have a variety of shapes, from circular to elongate (Roberts et al., 2009). Elongated mounds often have been related to the presence of an unidirectional bottom current regime, however, with elongated coral mounds sometimes occurring perpendicular (Correa et al., 2012a) and sometimes parallel (Messing et al., 1990) to the main current direction. The elongated coral mounds within the Campeche CWC province appear to be generally aligned parallel to the main current direction possibly following an upstream growth pattern as outlined by Messing et al. (1990). They mostly stretch towards $330^{\circ}$ with some heading towards $300^{\circ}$ (with a second-order direction NE-SW; see above). These directions are close to the two main current directions of $330^{\circ}$ (above $\sim 470 \mathrm{~m}$ ) and $360^{\circ}$ (below $\sim 470 \mathrm{~m}$ ) derived from the ADCP data (Fig. 8) which, however, only represent a snapshot in time. Temporal variations (e.g., lunar, seasonal) below $470 \mathrm{~m}$ might result in the different directions of the coral mounds observed. Then, the $30^{\circ}$ offset between both current directions and both mound directions observed could speculatively be related to an inherent $30^{\circ}$ relationship between coral mound extension and prevailing current direction.

\subsection{The Campeche cold-water corals and associated community}

The Campeche CWC province is constructed by Enallopsammia profunda and to a lesser degree by Lophelia pertusa. Neither of the scleractinians have been reported in previous publications from the Campeche slope (e.g., Cairns, 1979; Cairns et al., 1993) but are known from several locations in the Caribbean Sea and northern Gulf of Mexico (see compilations of published and unpublished information by Brooke and Schroeder, 2007; Lutz and Ginsburg, 2007; Messing et al., 2008). While L. pertusa has a nearly cosmopolitan distribution, E. profunda is endemic to the western Atlantic from the Antilles in the south to off Massachusetts in the north at water depths of 146-1748 m (Cairns, 1979). Structureforming Enallopsammia-Lophelia frameworks are known from the base of the Florida-Hatteras slope in 500-800 m water depth and from Miami to South Carolina (Reed, 2002). Correa et al. (2012a) describe an approximately $20 \mathrm{~km}^{2}$ field of Enallopsammia-Lophelia coral mounds at the base of the Miami Terrace, Straits of Florida, at $630-870 \mathrm{~m}$ depth, with a denser coral framework on current-facing flanks and summits. The same coral association is present in the CWC mound province at the toe of the Great Bahama Bank (Correa et al., 2012b). Interestingly, on the ROV tracks studied only a low abundance of associated megafauna in the Campeche CWC province was documented. This is in contrast to other scleractinian coral framework habitats in the northern Gulf of Mexico (Lessard-Pilon et al., 2010) or in the eastern North Atlantic (e.g., Henry and Roberts, 2007; Roberts et al., 2006). For instance, with the exception of 
Aphrocallistes sp. and a few Keratoisis sp., no other large suspension-feeding megabenthos were observed during the three ROV dives. It should be kept in mind that the visually inspected portion of the Campeche coral province is far too small for a solid conclusion at present and further inspections may change this first impression considerably.

Regarding the structure-forming CWC from the Campeche Bank on a wider perspective, this newly found CWC province is located at a key position, namely at the beginning of the Loop Current that passes over the well-known CWC occurrences of Louisiana and west Florida before it becomes the Florida Current flowing through the Straits of Florida. North of the Straits of Florida the Florida Current forms $90 \%$ of the Gulf Stream, passing north along the margins of South Carolina and Georgia, from where also large CWC provinces have been reported (Ross, 2007; Ross and Quattrini, 2007; Messing et al., 2008). South of the Campeche CWC province, Lophelia is known from off Brazil, Venezuela and Colombia and was recently mapped off Roatan, Honduras (Reyes et al., 2005; Lutz and Ginsburg, 2007; Arantes et al., 2009; Mangini et al., 2010; Etnoyer et al., 2011), thus following the path of the northward-flowing AAIW that bypasses the Campeche Bank (Merino, 1997). Such an oceanic intermediate water gateway (sensu Henry, 2011) may exert strong control on coral larval dispersal routes as has been documented for Desmophyllum dianthus populations in the South Pacific (Miller et al., 2011).

\subsection{Environmental control on the Campeche cold-water coral ecosystem}

The known ranges of temperature $\left(4-13.9{ }^{\circ} \mathrm{C}\right.$; Roberts et al., 2006; Freiwald et al., 2009), salinity (31.7-38.8; Freiwald et al., 2004; Davies et al., 2008), dissolved oxygen (2.7$7.2 \mathrm{mLL}^{-1}$; Dodds et al., 2007; Davies et al., 2008; Davies et al., 2010) and other physicochemical parameters defining the ecological niche of $L$. pertusa in the eastern North Atlantic (see summary in Davies et al., 2008) are found in many parts of the world's oceans (Davies and Guinotte, 2011). Water mass properties obtained for the Campeche margin, such as temperature $\left(9.5-7.5^{\circ} \mathrm{C}\right)$ and salinity $(35.1-34.9)$, fit well into these defined thresholds (Fig. 7). The observed content of dissolved oxygen of $\sim 2.7 \mathrm{mLL}^{-1}$ matches observations from the Viosca Knoll area in the northern Gulf of Mexico, where Lophelia colonies currently thrive at the lowest reported oxygen levels of 2.7-2.8 $\mathrm{mL} \mathrm{L}^{-1}$ (Davies et al., 2010). It is assumed that these extreme oxygen conditions cause decreased growth rates or even inhibit reproductive processes (Brooke and Young, 2003).

However, despite a suited physicochemical setting, the presence of suitable hardgrounds for the corals to settle on, and even more importantly the availability of sufficient food, is crucial for the establishment and long-lasting development of a vivid CWC ecosystem. In general CWC feed on fresh phytodetritus (Duineveld et al., 2004; Kiriakoulakis et al.,
2005; Duineveld et al., 2007), on zooplankton (Carlier et al., 2009; Dodds et al., 2009) or on a combination of both (Becker et al., 2009; van Oevelen et al., 2009). Recent laboratory studies also revealed the importance of dissolved organic matter which might be actively absorbed by CWC especially during periods when particulate food is scarce (Gori et al., in press). However, independent of the food source, the sessile CWC rely on sufficient food supply, which is based on primary production in the surface waters and the delivery of food particles to the CWC living at intermediate depths. For the latter, various mechanisms were identified to enhance and transport food particles to the CWC, including strong bottom currents, downwelling and cascading, internal tides and waves, and nepheloid layers which act as a pathway for lateral transport (White et al., 2005; Dorschel et al., 2007; Duineveld et al., 2007; Mienis et al., 2007; Davies et al., 2009; Orejas et al., 2009). On the local to regional scale, topography also influences hydrodynamic processes, as, e.g., internal waves, down- or upwelling. Thus, for any given location it is the interplay of all these factors allowing for or prohibiting the presence of CWC.

For the Campeche CWC province, the provision of food to the CWC appears to be almost optimal, and therefore the observed paucity of the coral-associated megafauna remains to be explained. Primary productivity in the surface waters is high (up to $\sim 1 \mathrm{mgChl} a \mathrm{~m}^{-3}$; Fig. 1) due to the local upwelling center that is located just above the Campeche CWC province (Merino, 1997). Current meter data from the Yucatan Strait (Sheinbaum et al., 2002) as well as the ADCP data collected during cruise MSM 20-4 reveal reasonably strong bottom currents with average velocities of $\sim 30 \mathrm{~cm} \mathrm{~s}^{-1}$ between 500 and $600 \mathrm{~m}$ water depth (Fig. 8). These numbers are in line with in situ current measurements at other CWC sites indicating maximum velocities of $>50 \mathrm{~cm} \mathrm{~s}^{-1}$ (Dorschel et al., 2007; Mienis et al., 2007), whereas average current velocities can be as low as $8 \mathrm{~cm} \mathrm{~s}^{-1}$ (Mienis et al., 2007).

Furthermore, the strong density gradient undulating around $520 \mathrm{~m}$ (Fig. 6d) might act as a decelerator for sinking (food) particles, thereby prolonging their residence time within the reach of the CWC and, thus, enhancing the probability of these particles to be caught by the corals. With salinities varying around 35 , this density gradient possibly marks the upper limit of the core of the AAIW. A similar mechanism has been suggested to support the CWC off Ireland, there benefitting from the density gradient developed at the upper limit of the Mediterranean Outflow Water (White and Dorschel, 2010). For the northeastern North Atlantic, Dullo et al. (2008) described a narrow potential density envelope of sigma-theta $\left(\sigma_{\Theta}\right)=27.35-27.65 \mathrm{~kg} \mathrm{~m}^{-3}$ preferred by the CWC. Along the Campeche Bank the density of the water masses surrounding the CWC is slightly lower, at 27.18$27.29 \mathrm{~kg} \mathrm{~m}^{-3}$, and, thus, close to data reported from the Viosca Knoll area (27.1-27.2 $\mathrm{kg} \mathrm{m}^{-3}$ ) (Davies et al., 2010). In contrast, living CWC settings in the Mediterranean Sea are 
associated with much higher densities of $>29 \mathrm{~kg} \mathrm{~m}^{-3}$. Thus, if applicable, the concept of a narrow density envelope defining the overall habitat range of the CWC as suggested by Dullo et al. (2008) needs to be regionalized (see also Flögel et al., in press). However, the obvious steep gradient in density (Fig. 6d) seems to be a sensitive indicator for living CWC reef communities.

As indicated by the undulating isotherms (Fig. 6), the temporal variability of the local hydrographic setting, which might reflect the presence of internal waves, literally might pump the food particles through the CWC ecosystem, especially those particles temporarily accumulating along the strong density gradient, as suggested by Mienis et al. (2012). Over the observed $13 \mathrm{~h}$, the depth range covered by the fluctuating maximum near-bottom density gradient aligns with the upper range of observed living CWC in $\sim 515-530 \mathrm{~m}$ water depth. Assuming a larger variability associated with monthly (i.e., lunar) to seasonal forcing, one may speculate that the entire depth range of living CWC off the Campeche Bank might intermittently be affected by such a pumping process. Due to the limited length of the $13 \mathrm{~h}$ of observation no tidal signal providing additional energy to the bottom current regime could have been clearly detected. However, along the mooring transect across the Yucatan Strait mentioned before (Sheinbaum et al., 2002), a comparably high amplitude of the major axis of the dominant diurnal $O_{1}$ tide was observed exactly in the depth range of the Campeche CWC province (Carrillo González et al., 2007).

The ADCP data also point to another possible food source for the corals. The strong upward-rising backscatter signal at dusk and the down-going signal at dawn (Fig. 7) are indicative of the diel vertical migration of zooplankton (Heywood, 1996). According to the backscatter data shown in Fig. 7 the migrating zooplankton spend the day at depths of $>300 \mathrm{~m}$, with any deeper-reaching migration being obscured by bottom interferences of the backscatter signal. In case the zooplankton actively descend to the depths of the CWC, it might serve as an additional process enhancing the delivery of food to the CWC. The depth range of the Campeche CWC is often reached by migrating zooplankton. For instance, off the California coast, a depth of $\sim 560 \mathrm{~m}$ has been shown to be a preferred depth of the zooplankton at which to spend the daytime (Plüddemann and Pinkel, 1989). The potential of daily migrating zooplankton as an additional food source for the CWC has also been put forward by Mienis et al. (2012) based on ADCP observations in the Viosca Knoll area in the northern Gulf of Mexico.

\section{Conclusions}

The Campeche CWC province is one of the largest coherent CWC areas discovered so far, and the most relevant in the western Atlantic Ocean. A healthy and highly diverse CWC ecosystem is developed on top of a complex system of 20-40 m-high, partly interconnected elongated mounds, which probably can serve as a paleoenvironmental archive enabling the reconstruction of the long-term development of the Campeche CWC province over the Late Quaternary climatic cycles.

The location of the Campeche CWC province appears to be almost perfect for the establishment of such a large CWC ecosystem. It is (a) located underneath a local upwelling center providing high primary production, (b) influenced by a very dynamic bottom current regime delivering food particles to the corals, and (c) characterized by a physicochemical setting that fits the recognized ecological needs of $L$. pertusa. The observed diel vertical migration of zooplankton possibly reaching the intermediate depth of the CWC ecosystem may even serve as a supplemental food source as already indicated by Mienis et al. (2012). These observations fits several paleoenvironmental studies, highlighting the controlling role of the food supply on the long-term development of such ecosystems (Dorschel et al., 2005; Wienberg et al., 2010; Eisele et al., 2011; Fink et al., 2013).

In many places in the world's oceans the physicochemical setting comply with the niche requirements of $L$. pertusa and other CWC (Davies and Guinotte, 2011); however, only in some of these places have CWC ecosystems developed. Thus, the Campeche CWC province appears to be an excellent example showing that food supply - controlled by a variety of mechanisms - plays a major role in the development of CWC ecosystems.

Acknowledgements. The research leading to these results has received support from the Deutsche Forschungsgemeinschaft (DFG) through funding of the WACOM - West Atlantic Cold-water Coral Ecosystems projects, grants HE 3412/17-1 and DU 129/47-1, and through providing ship time. We thank the officers and crew of the R/V Maria S. Merian, the MARUM ROV Cherokee team, and the scientific crew for on-board assistance during cruise MSM 20-4 (2012). The cruise was further supported through the DFG Research Center/Cluster of Excellence "MARUM - The Ocean in the Earth System". We are grateful to the Mexican Government for providing access to conduct scientific work in Mexican waters. A. Freiwald received funds from the Hessian LOEWE BiK-F Project A3.10, and G. P. Eberli acknowledges the donors of the American Chemical Society Petroleum Research Fund (grant no. 49017-ND8) for partial support of this research and the industrial associates of the CSL - Center for Carbonate Research at the University of Miami for additional funding. L. Matos has been supported by the FCT scholarship SFRH/BD/72149/2010. This is ISMAR-CNR Bologna scientific contribution no. 1801. This study contributes to the international research program TRACES Trans-Atlantic Coral Ecosystem Study.

Edited by: J. Bijma 


\section{References}

Arantes, R. C. M., Castro, C. B., Pires, D. O., and Seoane, J. C. S.: Depth and water mass zonation and species associations of coldwater octocoral and stony coral communities in the southwestern Atlantic, Mar. Ecol.-Prog. Ser., 397, 71-79, 2009.

Becker, E. L., Cordes, E. E., Macko, S. A., and Fisher, C. R.: Importance of seep primary production to Lophelia pertusa and associated fauna in the Gulf of Mexico, Deep-Sea Res. Pt. I, 56, 786-800, 2009.

Brooke, S. and Schroeder, W. W.: State of the U.S. deep coral ecosystems in the northern Gulf of Mexico region: Florida Straits to Texas, in: The State of Deep Coral Ecosystems of the United States, edited by: Lumsden, S. E., Hourigan, T. F., and Bruckner, A. W., NOAA Technical Memorandum CRCP-3, Silver Spring MD, 271-306, 2007.

Brooke, S. and Young, C. M.: Reproductive ecology of a deep-water scleractinian coral, Oculina varicosa, from the southeast Florida shelf, Cont. Shelf Res., 23, 847-858, 2003.

Brooke, S. D., Holmes, M. W., and Young, C. M.: Sediment tolerance of two different morphotypes of the deep-sea coral Lophelia pertusa from the Gulf of Mexico, Mar. Ecol.-Prog. Ser., 390, 137-144, 2009.

Buhl-Mortensen, L. and Mortensen, P. B.: Symbiosis in deep-water corals, Symbiosis, 37, 33-61, 2004.

Cairns, S. D.: The Deep-Water Scleractinia of the Caribbean Sea and Adjacent Waters, Studies on the Fauna of Curaçao and Other Caribbean Islands, 57, 341 pp., 1979.

Cairns, S. D., Opresko, D. M., Hopkins, T. S., and Schroeder, W. W.: New records of deep-water Cnidaria (Scleractinia and Antipatharia) from the Gulf of Mexico, Northeast Gulf Science, 13, $1-11,1993$.

Caress, D. W. and Chayes, D. N.: Improved processing of Hydrosweep DS Multibeam Data on the R/V MAURICE EWING, Geophys. Res., 18, 631-650, 1996.

Carlier, A., Le Guilloux, E., Olu-Le Roy, K., Sarrazin, J., Mastrototaro, F., Taviani, M., and Clavier, J.: Trophic relationships in a deep Mediterranean cold-water coral bank (Santa Maria di Leuca, Ionian Sea), Mar. Ecol.-Prog. Ser., 397, 125-137, 2009.

Carrillo González, F., Ochoa, J., Candela, J., Badan, A., Sheinbaum, J., and González Navarro, J. I.: Tidal currents in the Yucatan Channel, Geof. Int., 46, 199-209, 2007.

Caruso, J. H., Ross, S. W., Sulak, K. J., and Sedberry, G. R.: Deepwater chaunacid and lophiid anglerfishes (Pisces: Lophiiformes) off the south-eastern United States, J. Fish Biol., 70, 1015-1026, 2007.

Colman, J. G., Gordaon, D. M., Lane, A. P., Forde, M. J., and Fitzpatrick, J.: Carbonate mounds off Mauretania, Northwest Africa: status of deep-water corals and implications for management of fishing and oil exploration activities, in: Cold-water Corals and Ecosystems, edited by: Freiwald, A., and Roberts, J. M., Springer, Berlin-Heidelberg, 417-441, 2005.

Cordes, E. E., McGinley, M. P., Podowski, E. L., Becker, E. L., Lessard-Pilon, S., Viada, S. T., and Fisher, C. R.: Coral communities of the deep Gulf of Mexico, Deep-Sea Res. Pt. I, 55, 777-787, 2008.

Correa, T. B. S., Eberli, G. P., Grasmueck, M., Reed, J. K., and Correa, A. M. S.: Genesis and morphology of cold-water coral ridges in a unidirectional current regime, Mar. Geol., 326-328, 14-27, 2012a.
Correa, T. B. S., Grasmueck, M., Eberli, G. P., Reed, J. K., Verwer, K., and Purkis, S. A. M.: Variability of cold-water coral mounds in a high sediment input and tidal current regime, Straits of Florida, Sedimentology, 59, 1278-1304, 2012b.

Davies, A. J. and Guinotte, J. M.: Global habitat suitability for framework-forming cold-water corals, Plos One, 6, e18483, doi:10.1371/journal.pone.0018483, 2011.

Davies, A. J., Wisshak, M., Orr, J. C., and Roberts, J. M.: Predicting suitable habitat for the cold-water coral Lophelia pertusa (Scleractinia), Deep-Sea Res. Pt. I, 55, 1048-1062, 2008.

Davies, A. J., Duineveld, G., Lavaleye, M., Bergman, M. J., van Haren, H., and Roberts, J. M.: Downwelling and deep-water bottom currents as food supply mechanisms to the cold-water coral Lophelia pertusa (Scleractinia) at the Mingulay Reef Complex, Limnol. Oceanogr., 54, 620-629, doi:10.4319/lo.2009.54.2.0620, 2009.

Davies, A. J., Duineveld, G. C. A., van Weering, T. C. E., Mienis, F., Quattrini, A. M., Seim, H. E., Bane, J. M., and Ross, S. W.: Short-term environmental variability in cold-water coral habitat at Viosca Knoll, Gulf of Mexico, Deep-Sea Res. Pt. I, 57, 199212, 2010.

Deines, K. L.: Backscatter estimation using broadband acoustic Doppler current profilers, Proceedings of the Sixth Working Conference on Current Measurement, San Diego, CA, IEEE, 249253, 1999.

Dodds, L. A., Roberts, J. M., Taylor, A. C., and Marubini, F.: Metabolic tolerance of the cold-water coral Lophelia pertusa (Scleractinia) to temperature and dissolved oxgen change, J. Experim. Mar. Biol. Ecol., 349, 205-214, 2007.

Dodds, L. A., Black, K. D., Orr, H., and Roberts, J. M.: Lipid biomarkers reveal geographical differences in food supply to the cold-water coral Lophelia pertusa (Scleractinia), Mar. Ecol.Prog. Ser., 397, 113-124, 2009.

Dorschel, B., Hebbeln, D., Rüggeberg, A., and Dullo, W.-C.: Growth and erosion of a cold-water coral covered carbonate mound in the Northeast Atlantic during the Late Pleistocene and Holocene, Earth Planet. Sci. Lett., 233, 33-44, 2005.

Dorschel, B., Hebbeln, D., Foubert, A., White, M., and Wheeler, A. J.: Hydrodynamics and cold-water coral facies distribution related to recent sedimentary processes at Galway Mound west of Ireland, Mar. Geol., 244, 184-195, 2007.

Dorschel, B., Wheeler, A., Monteys, X., and Verbruggen, K.: Atlas of the Deep-Water Seabed: Ireland, Springer, 164 pp., 2010.

Douarin, M., Elliot, M., Noble, S. R., Sinclair, D., Henry, L.-A., Long, D., Moreton, S. G., and Murray Roberts, J.: Growth of north-east Atlantic cold-water coral reefs and mounds during the Holocene: A high resolution U-series and 14C chronology, Earth Planet. Sci. Lett., 375, 176-187, 2013.

Duineveld, G. C. A., Lavleye, M. S. S., and Berghuis, E. M.: Particle flux and food supply to a seamount cold-water coral community (Galicia Bank, NW Spain), Mar. Ecol.-Prog. Ser., 277, 13-23, 2004.

Duineveld, G. C. A., Lavaleye, M. S. S., Bergman, M. J. N., De Stigter, H., and Mienis, F.: Trophic structure of a cold-water coral mound community (Rockall Bank, NE Atlantic) in relation to the near-bottom particle supply and current regime, B. Mar. Sci., 81, 449-467, 2007.

Dullo, W.-C., Flögel, S., and Rüggeberg, A.: Cold-water coral growth in relation to the hydrography of the Celtic and Nordic 
European continental margin, Mar. Ecol.-Prog. Ser., 371, 165176, 2008.

Duncan, P. M.: A description of the Madreporaria dredged up during the expeditions of HMS Porcupine in 1869 and 1870. Part I, Trans. Zool. Soc. London, 8, 303-344, 1873.

Eisele, M., Hebbeln, D., and Wienberg, C.: Growth history of a cold-water coral covered carbonate mound - Galway Mound, Porcupine Seabight, NE-Atlantic, Mar. Geol., 253, 160-169, 2008.

Eisele, M., Frank, N., Wienberg, C., Hebbeln, D., López Correa, M., Douville, E., and Freiwald, A.: Productivity controlled coldwater coral growth periods during the last glacial off Mauritania, Mar. Geol., 280, 143-149, 2011.

Etnoyer, P., Shirley, T., and Lavelle, K. A.: Deep coral and associated species taxonomy and ecology (DeepCAST) II expedition report, NOAA Technical Memorandum. NOAA/NOS Center for Coastal Environmental Health and Biomolecular Research, Charleston, 1-42, 2011.

Fink, H. G., Wienberg, C., Hebbeln, D., McGregor, H. V., Schmiedl, G., Taviani, M., and Freiwald, A.: Oxygen control on Holocene cold-water coral development in the eastern Mediterranean Sea, Deep-Sea Res. Pt. I, 62, 89-96, 2012.

Fink, H. G., Wienberg, C., De Pol-Holz, R., Wintersteller, P., and Hebbeln, D.: Cold-water coral growth in the Alboran Sea related to high productivity during the Late Pleistocene and Holocene, Mar. Geol., 339, 71-82, 2013.

Flögel, S., Dullo, W. C., Pfannkuche, O., Kiriakoulakis, K., and Rüggeberg, A.: Geochemical and physical constraints for the occurrence of living cold-water corals, Deep-Sea Res. Pt. II, 99, 19-26, 2014.

Fosså, J. H., Lindberg, B., Christensen, O., Lundälv, T., Svellingen, I., Mortensen, P. B., and Alsvag, J.: Mapping of Lophelia reefs in Norway: experiences and survey methods, in: Cold-water Corals and Ecosystems, edited by: Freiwald, A., and Roberts, J. M., Springer, Berlin-Heidelberg, 359-391, 2005.

Frank, N., Ricard, E., Lutringer-Paquet, A., van der Land, C., Colin, C., Blamart, D., Foubert, A., Van Rooij, D., Henriet, J.-P., de Haas, H., and van Weering, T.: The Holocene occurrence of cold water corals in the NE Atlantic: Implications for coral carbonate mound evolution, Mar. Geol., 266, 129-142, 2009.

Freiwald, A. and Roberts, J. M.: Cold-water Corals and Ecosystems, Springer, Berlin-Heidelberg, 1243 pp., 2005.

Freiwald, A., Hühnerbach, V., Lindberg, B., Wilson, J. B., and Campbell, J.: The Sula Reef Complex, Norwegian Shelf, Facies, 47, 179-200, 2002

Freiwald, A., Fosså, J. H., Grehan, A., Koslow, T., and Roberts, J. M.: Cold-water Coral Reefs, UNEP-WCMC, Cambridge, UK, Biodiversity Series 22, 84 pp., 2004.

Freiwald, A., Beuck, L., Rüggeberg, A., Taviani, M., Hebbeln, D., and R/V Meteor Cruise M70-1 participants: The white coral community in the central Mediterranean Sea revealed by ROV surveys, Oceanography, 22, 58-74, 2009.

Gori, A., Orejas, C., Madurell, T., Bramanti, L., Martins, M., Quintanilla, E., Marti-Puig, P., Lo Iacono, C., Puig, P., Requena, S., Greenacre, M., and Gili, J. M.: Bathymetrical distribution and size structure of cold-water coral populations in the Cap de Creus and Lacaze-Duthiers canyons (northwestern Mediterranean), Biogeosciences, 10, 2049-2060, doi:10.5194/bg-102049-2013, 2013.
Gori, A., Grover, R., Orejas, C., Sikorski, S., and Ferrier-Pagès, C.: Uptake of dissolved free amino acids by four cold-water coral species from the Mediterranean Sea, Deep-Sea Res. Pt. II, 99, 42-50, 2014.

Grasmueck, M., Eberli, G. P., Viggiano, D. A., Correa, T., Rathwell, G., and Luo, J.: Autonomous underwater vehicle (AUV) mapping reveals coral mound distribution, morphology, and oceanography in deep water of the Straits of Florida, Geophys. Res. Lett., 33, L23616, doi:10.1029/2006GL027734, 2006.

Hebbeln, D., Wienberg, C., and cruise participants: Report and preliminary results of R/V MARIA S. MERIAN cruise MSM204, WACOM - West-Atlantic Cold-water Coral Ecosystems: The West Side Story, Bridgetown - Freeport, 14 March-7 April 2012, University of Bremen, 120 pp., 2012.

Henry, L. A.: A deep-sea coral "gateway" in the Northwestern Carribbean, in: Too precious to drill: The marine biodiversity of Belize, edited by: Palomares, M. L. D. and Pauly, D., Fisheries Centre Research Reports, 120-124, 2011.

Henry, L. A. and Roberts, J. M.: Biodiversity and ecological composition of macrobenthos on cold-water coral mounds and adjacent off-mound habitat in the bathyal Porcupine Seabight, NE Atlantic. Deep Sea Res. Part I, 54, 654-672, 2007.

Heywood, V. H.: The Global Biodiversity Assessment, The Globe, 30, 2-4, 1996.

Hübscher, C., Dullo, W. C., Flögel, S., Titschack, J., and Schönfeld, J.: Contourite drift evolution and related coral growth in the eastern Gulf of Mexico and its gateways, Int. J. Earth Sci., 99, S191-S206, 2010.

Kano, A., Ferdelman, T. G., Williams, T., Henriet, J.-P., Ishikawa, T., Kawagoe, N., Takashima, C., Kakizaki, Y., Abe, K., Sakai, S., Browning, E. L., Li, X., and Integrated Ocean Drilling Program Expedition 307 Scientists: Age constraints on the origin and growth history of a deep-water coral mound in the northeast Atlantic drilled during Integrated Ocean Drilling Program Expedition 307, Geology, 35, 1051-1054, 2007.

Kenyon, N. H., Akhmetzhanov, A. M., Wheeler, A. J., van Weering, T. C. E., de Haas, H., and Ivanov, M. K.: Giant carbonate mud mounds in the southern Rockall Trough, Mar. Geol., 195, 5-30, 2003.

Kiriakoulakis, K., Harper, E., and Wolff, G. A.: Lipids and nitrogeen isotopes of two deep-water corals from the North-East Atlantic: initial results and implications for their nutrition, in: Cold-water Corals and Ecosystems, edited by: Freiwald, A., and Roberts, J. M., Springer, Berlin-Heidelberg, 715-729, 2005.

Le Guilloux, E., Olu-Le Roy, K., Bourillet, J. F., Savoye, B., Iglésias, S. P., and Sibuet, M.: First observations of deep-sea coral reefs along the Angola margin, Deep-Sea Res. Pt. II, 56, 2394-2403, 2009.

Lessard-Pilon, S., Podowski, E. L., Cordes, E. E., and Fisher, C. R.: Megafauna community composition associated with Lophelia pertusa colonies in the Gulf of Mexico. Deep-Sea Res. Part II, 57, 1882-1890, 2010.

López Correa, M., Montagna, P., Joseph, N., Rüggeberg, A., Fietzke, J., Flögel, S., Dorschel, B., Goldstein, S. L., Wheeler, A., and Freiwald, A.: Preboreal onset of cold-water coral growth beyond the Arctic Circle revealed by coupled radiocarbon and Useries dating and neodymium isotopes, Quat. Sci. Rev., 34, 24 43, 2012. 
Lutz, S. J. and Ginsburg, R. N.: State of the U.S. deep coral ecosystems in the United States Caribbean region: Puerto Rico and U.S. Virgin Islands, in: The State of Deep Coral Ecosystems of the United States, edited by: Lumsden, S. E., Hourigan, T. F., and Bruckner, A. W., NOAA Technical Memorandum CRCP-3, Silver Spring MD, 307-365, 2007.

Mah, C., Nizinski, M., and Lundsten, L.: Phylogenetic revision of the Hippasterinae (Goniasteridae; Asteroidea): systematics of deep sea corallivores, including one new genus and three new species, Zool. J. Linnean Soc., 160, 266-301, 2010.

Mangini, A., Godoy, J. M., Godoy, M. L., Kowsmann, R., Santos, G. M., Ruckelshausen, M., Schroeder-Ritzrau, A., and Wacker, L.: Deep sea corals off Brazil verify a poorly ventilated Southern Pacific Ocean during H2, H1 and the Younger Dryas, Earth Planet. Sci. Lett., 293, 269-276, 2010.

Merino, M.: Upwelling on the Yucatan Shelf: hydrographic evidence, J. Marine Syst., 13, 101-121, 1997.

Messing, C. G., Neumann, A. C., and Lang, J. C.: Biozonation of deep-water lithoherms and associated hardgrounds in the northeastern Straits of Florida, Palaois, 5, 15-33, 1990.

Messing, C. G., Reed, J. K., Brooke, S. D., and Ross, S. W.: DeepWater Coral Reefs of the United States, in: Coral Reefs of the USA, edited by: Riegl, B. and Dodge, R. E., Springer, 763-787, 2008.

Mienis, F., de Stigter, H. C., White, M., Duineveld, G., de Haas, H., and van Weering, T. C. E.: Hydrodynamic controls on cold-water coral growth and carbonate-mound development at the SW and SE Rockall Trough Margin, NE Atlantic Ocean, Deep-Sea Res. Pt. I, 54, 1655-1674, 2007.

Mienis, F., Duineveld, G. C. A., Davies, A. J., Ross, S. W., Seim, H., Bane, J., and Van Weering, T. C. E.: The influence of nearbed hydrodynamic conditions on cold-water corals in the Viosca Knoll area, Gulf of Mexico, Deep-Sea Res. Pt. I, 60, 32-45, 2012.

Miller, K. J., Rowden, A. A., Williams, A., and Häussermann, V.: Out of their depth? Isolated deep populations of the cosmopolitan coral Desmophyllum dianthus may be highly vulnerable to environmental change, Plos One, 6, e19004, doi:10.1371/journal.pone.0019004, 2011.

Molinari, R. L. and Morrison, J.: The separation of the Yucatan Current from the Campeche Bank and the intrusion of the Loop Current into the Gulf of Mexico, J. Geophysic. Res., 93, 1064510654, 1988.

Moore, D. R. and Bullis, H. R.: A deep-water coral reef in the Gulf of Mexico, Bull. Mar. Sci. Gulf Caribbean, 10, 125-128, 1960.

Moseley, H. N.: Report on certain hydroid, alcyonarian, and madreporarian corals procured during the voyage of H.M.S. Challenger, in the years 1873-1876. Report of Scientific Research of H.M.S. Challenger, Zoology, 2, 1-248, 1881.

Mueller, C. E., Lundälv, T., Middelburg, J. J., and Van Oevelen, D.: The symbiosis between Lophelia pertusa and Eunice norvegica stimulates coral calcification and worm assimilation, Plos One, 8, e58660, doi:10.1371/journal.pone.0058660, 2013.

Müller-Karger, F. E., Walsh, J. J., Evans, R. H., and Meyers, M. B.: On the seasonal phytoplankton concentration and sea surface temperature cycles of the Gulf of Mexico as determined by satellites, J. Geophysic. Res., 96, 12645-12665, 1991.

Mullins, H. T., Newton, C. R., Heath, K., and Vanburen, H. M.: Modern deep-water coral mounds north of Little Bahama Bank: criteria for recognition of deep-water coral bioherms in the rock record, J. Sed. Petrol., 51, 999-1013, 1981.

Neumann, A. C. and Ball, M. M.: Submersible observations in Straits of Florida - geology and bottom currents, Geol. Soc. Americ. Bull., 81, 2861-2873, 1970.

Neumann, A. C., Kofoed, J. W., and Keller, G. H.: Lithoherms in the Straits of Florida, Geology, 5, 4-10, 1977.

Newton, C. R., Mullins, H. T., and Gardulski, A. F.: Coral mounds on the West Florida Slope: unanswered questions regarding the development of deepwater banks, Palaois, 2, 359-367, 1987.

Orejas, C., Gori, A., Lo Iacono, C., Puig, P., Gili, J. M., and Dale, M. R.: Cold-water corals in the Cap de Creus canyon (north-western Mediterranean): spatial distribution, density and anthropogenic impact, Mar. Ecol.-Prog. Ser., 397, 37-51, 2009.

Paull, C. K., Neumann, A. C., am Ende, B. A., Ussler III, W., and Rodriguez, N. M.: Lithoherms on the Florida-Hatteras slope, Mar. Geol., 166, 83-101, 2010.

Plüddemann, A. J., and Pinkel, R.: Characterization of the patterns of diel migration using a doppler sonar, Deep-Sea Res., 36, 509530, 1989.

Reed, J. K.: Comparison of deep-water coral reefs and lithoherms off southeastern USA, Hydrobiol., 471, 57-60, 2002.

Reed, J. K., Weaver, D., and Pomponi, S. A.: Habitat and fauna of deep-water Lophelia pertusa coral reefs off the Southeastern USA: Blake Plateau, Straits of Florida, and Gulf of Mexico, B. Mar. Sci., 78, 343-375, 2006.

Reyes, J., Santodomingo, N., Gracia, A., Borrero-Pérez, G., Navas, G., Mejía-Ladino, L. M., Bermudéz, A., and Benavidos, M.: Southern Caribbean azooxanthellate coral communities off Colombia, in: Cold-water Corals and Ecosystems, edited by: Freiwald, A., and Roberts, J. M., Springer, Berlin-Heidelberg, 309-330, 2005.

Roberts, J. M., Wheeler, A. J., and Freiwald, A.: Reefs of the deep: The biology and geology of cold-water coral ecosystems, Science, 312, 543-547 2006.

Roberts, J. M., Wheeler, A. J., Freiwald, A., and Cairns, S. D.: Coldwater corals. The biology and geology of deep-sea coral habitats, Cambridge University Press, 336 pp., 2009.

Ross, S. W.: Unique deep-water ecosystems off the southeastern United States, Oceanography, 20, 130-139, 2007.

Ross, S. W. and Nizinski, M. S.: State of the U.S. deep coral ecosystems in the southeastern United States region: Cape Hatteras to the Florida Straits, in: The State of Deep Coral Ecosystems of the United States, edited by: Lumsden, S. E., Hourigan, T. F., and Bruckner, A. W., NOAA Technical Memorandum CRCP-3, Silver Spring MD, 233-270, 2007.

Ross, S. W. and Quattrini, A. M.: The fish fauna associated with deep coral banks off the southeastern United States, Deep-Sea Res. Pt. I, 54, 975-1007, 2007.

Sanamyan, N. P., Sanamyan, K. E., and Tabachnick, K. R.: The first species of Actiniaria, Spongiactis japonica gen.n., sp.n. (Cnidaria: Anthozoa), an obligate symbiont of a glass sponge, Invert. Zool., 9, 127-141, 2012.

Savini, A., Vertino, A., Marchese, F., Beuck, L., and Freiwald, A.: Mapping Cold-Water Coral Habitats at Different Scales within the Northern Ionian Sea (Central Mediterranean): An Assessment of Coral Coverage and Associated Vulnerability, PLoS ONE, 9, e87108, doi:10.1371/journal.pone.0087108, 2014. 
Schroeder, W. W.: Observations of Lophelia pertusa and the surficial geology at a deep-water site in the northeastern Gulf of Mexico, Hydrobiol., 471, 29-33, 2002.

Schroeder, W. W., Brooke, S. D., Olson, J. B., Phaneuf, B., McDonough, J. J., and Etnoyer, P.: Occurrence of deep-water Lophelia pertusa and Madrepora oculata in the Gulf of Mexico, in: Cold-water Corals and Ecosystems, edited by: Freiwald, A. and Roberts, J. M., Springer, Berlin-Heidelberg, 297-307, 2005.

Schulkin, M. and Marsh, H. W.: Sound absorption in seawater, J. Acoust. Soc. Am., 34, 864-865, 1962.

Sheinbaum, J., Candela, J., Badan, A., and Ochoa, J.: Flow structure and transport in the Yucatan Channel, Geophys. Res. Lett., 29, 1040, doi:10.1029/2001GL013990, 2002.

Stevenson, A. and Rocha, C.: Evidence for the bioerosion of deepwater corals by echinoids in the Northeast Atlantic, Deep-Sea Res. Pt. I, 71, 73-78, 2013.

Taviani, M., Angeletti, L., Dimech, M., Mifsud, C., Freiwald, A., Harasewych, M. G., and Oliverio, M.: Coralliophilinae (Gastropoda: Muricidae) associated with deep-water coral banks in the Mediterranean, The Nautilus, 123, 106-112, 2009.

Thierens, M., Browning, E., Pirlet, H., Loutre, M. F., Dorschel, B., Huvenne, V. A. I., Titschack, J., Colin, C., Foubert, A., and Wheeler, A. J.: Cold-water coral carbonate mounds as unique palaeo-archives: the Plio-Pleistocene Challenger Mound record (NE Atlantic), Quaternary Sci. Rev., 73, 14-30, 2013.

Titschack, J., Thierens, M., Dorschel, B., Schulbert, C., Freiwald, A., Kano, A., Takashima, C., Kawagoe, N., and Li, X.: Carbonate budget of a cold-water coral mound (Challenger Mound, IODP Exp. 307), Mar. Geol., 259, 36-46, 2009.

van Oevelen, D., Duineveld, G., Lavaleye, M., Mienis, F., Soetaert, K., and Heip, C. H. R.: The cold-water coral community as a hot spot for carbon cycling on continental margins: A food-web analysis from Rockall Bank (northeast Atlantic), Limnol. Oceanogr., 54, 1829-1844, 2009.

Van Rooij, D., De Mol, B., Huvenne, V., Ivanov, M., and Henriet, J. P.: Seismic evidence of current-controlled sedimentation in the Belgica mound province, upper Porcupine slope, southwest of Ireland, Mar. Geol., 195, 31-53, 2003.
Wawrik, B. and Paul, J. H.: Phytoplankton community structure and productivity along the axis of the Mississippi River Plume in oligotrophic Gulf of Mexico waters, Aqua. Microb. Ecol., 35, 185-196, 2004.

Wei, C. L., Rowe, G. T., Escobar-Briones, E., Nunnally, C., Soliman, Y., and Ellis, N.: Standing stocks and body size of deep-sea macrofauna: Predicting the baseline of 2010 Deepwater Horizon oil spill in the northern Gulf of Mexico, Deep-Sea Res. Pt. I, 69, 82-99, 2012.

Wessel, P. and Smith, W. H. F.: New, improved version of Generic Mapping Tools released, EOS, 79, p. 579, doi:10.1029/98EO00426, 1998

White, M. and Dorschel, B.: The importance of the permanent thermocline to the cold water coral carbonate mound distribution in the NE Atlantic, Earth Planet. Sci. Lett., 296, 395-402, 2010.

White, M., Mohn, C., de Stigter, H., and Mottram, G.: Deep-water coral development as a function of hydrodynamics and surface productivity around the submarine banks of the Rockall Trough, NE Atlantic, in: Cold-Water Corals and Ecosystems, edited by: Freiwald, A. and Roberts, J. M., Springer, Berlin-Heidelberg, 503-514, 2005.

Wienberg, C., Hebbeln, D., Fink, H. G., Mienis, F., Dorschel, B., Vertino, A., López Correa, M., and Freiwald, A.: Scleractinian cold-water corals in the Gulf of Cádiz - first clues about their spatial and temporal distribution, Deep-Sea Res. Pt. I, 56, 1873 1893, 2009.

Wienberg, C., Frank, N., Mertens, K. N., Stuut, J.-B., Marchant, M., Fietzke, J., Mienis, F., and Hebbeln, D.: Glacial cold-water coral growth in the Gulf of Cádiz: Implications of increased palaeoproductivity, Earth Planet. Sci. Lett., 298, 405-416, 2010.

Zavala-Hidalgo, J., Gallegos-García, A., Martínez-López, B., Morey, S. L., and O'Brien, J. J.: Seasonal upwelling on the Western and Southern Shelves of the Gulf of Mexico, Ocean Dynam. 56, 333-338, 2006. 